\title{
ValpoScholar
}

Valparaiso University Law Review

Volume 49

Number 3 Spring 2015

pp.659-721

Spring 2015

\section{Using the DNA Testing of Arrestees to Reevaluate Fourth Amendment Doctrine}

Steven P. Grossman

Follow this and additional works at: https://scholar.valpo.edu/vulr

Part of the Law Commons

\section{Recommended Citation}

Steven P. Grossman, Using the DNA Testing of Arrestees to Reevaluate Fourth Amendment Doctrine, 49 Val. U. L. Rev. 659 (2015).

Available at: https://scholar.valpo.edu/vulr/vol49/iss3/8

This Article is brought to you for free and open access by the Valparaiso University Law School at ValpoScholar. It has been accepted for inclusion in Valparaiso University Law Review by an authorized administrator of ValpoScholar. For more information, please contact a ValpoScholar staff member at scholar@valpo.edu. 


\section{USING THE DNA TESTING OF ARRESTEES TO REEVALUATE FOURTH AMENDMENT DOCTRINE}

\section{Steven P. Grossman*}

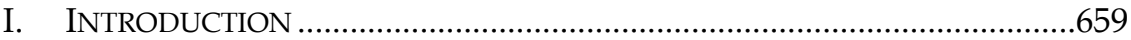

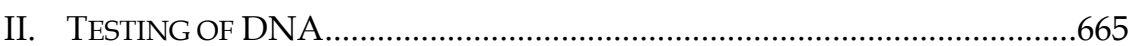

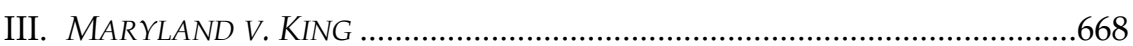

IV. PRESUMPTION OF INNOCENCE ..............................................................672

V. THE BALANCING TEST FOR REASONABLENESS UNDER THE FOURTH

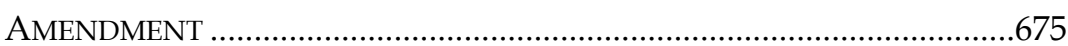

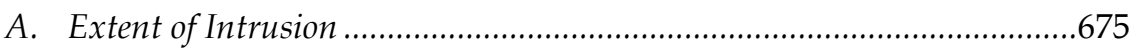

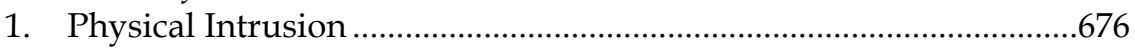

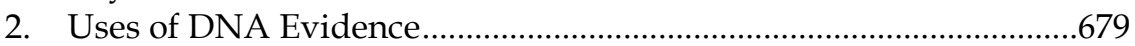

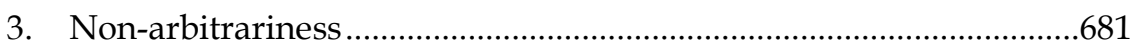

B. Nature of Government Interest .............................................................684

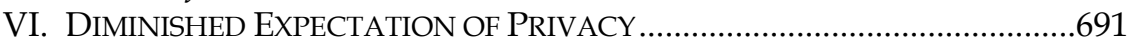

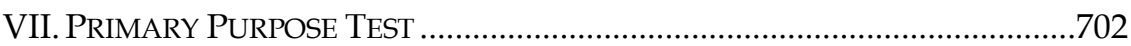

A. The Primary Purpose Test as it Relates to the DNA Testing of

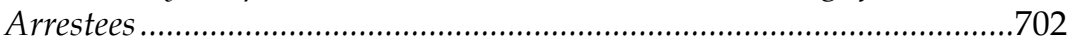

B. The Test is Unclear in its Definition and Inconsistent in its

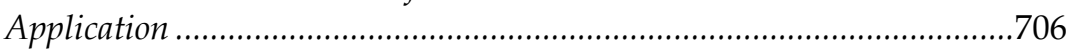

C. The Test Protects the Wrong People and for No Good Reason...................715

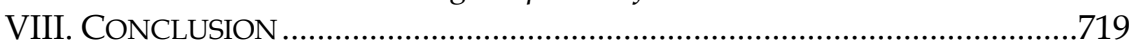

\section{INTRODUCTION}

With the advent of DNA testing, numerous issues have arisen in regard to obtaining and using evidence that results from such testing. As courts have come to regard DNA testing as a reliable method for linking some people to crimes and for exonerating others, these issues are especially significant. ${ }^{1}$ The federal government and most states have

\footnotetext{
The author is the Dean Julius Isaacson Professor at the University of Baltimore School of Law. He would like to thank Matthew Gannett and Erika Flaschner for their invaluable assistance in the preparation of this Article.

1 See Lisa Carrabino, Note, The Admissibility of DNA Typing and Statistical Probability Evidence, 29 SufFolK U. L. REV. 473, 495 n.156 (1995) (citing State v. Moore, 885 P.2d 457, 468 (Mont. 1994), overruled on other grounds by State v. Gollehon, 906 P.2d 697 (Mont. 1995); State v. Cauthron, 846 P.2d 502, 512 (Wash. 1993) (en banc); People v. Castro, 545 N.Y.S.2d 985, 986-88 (Sup. Ct. 1989)) (discussing the admissibility of DNA testing in the states); see also Veronia Valdivieso, Note, DNA Warrants: A Panacea for Old Rape Cases?, 90 GEO. L.J. 1009, 1021 n.98 (2002) (referencing cases such as Smith v. Deppish, 807 P.2d 144, 159 (Kan. 1991); Mandujano v. State, 799 S.W.2d 318, 321-22 (Tex. Ct. App. 1990); Snowden v. State, 574 So. 2d 960, 966 (Ala. Crim. App. 1990); State v. Schwartz, 447 N.W.2d 422, 426 (Minn. 1989)).
} 
Valparaiso University Law Review, Vol. 49, N0. 3 [2015], Art. 8

enacted statutes that permit or direct the testing of those convicted of certain crimes. ${ }^{2}$ Courts have almost universally approved such testing, rejecting arguments that obtaining and using such evidence violates the Fourth Amendment. ${ }^{3}$

More recently, the government has enacted laws permitting or directing the taking of DNA samples from those arrested for, but not yet convicted of, certain serious crimes. ${ }^{4}$ Courts had been far more divided about the constitutionality of DNA testing for arrestees than they were for the comparable testing of those already convicted. ${ }^{5}$ Given the division in the holdings among both state and federal courts and the increasing importance of DNA evidence in criminal investigations, it is hardly surprising that the Supreme Court agreed to hear a case regarding the constitutionality of a Maryland statute allowing for such testing. ${ }^{6}$

2 See, e.g., 42 U.S.C. \$14135a (2006) (listing the crimes that require arrestees to have a DNA sample taken); see also Richard Williams \& Sarah Hammond, Building Forensic Technology Capacity, NAT'L CONF. STATE LEGIS. 17-19 (2009), available at http://www.ncsl.org/portals/1/documents/cj/forensictechnology09.pdf, archived at http://perma.cc/LSK2-FPU6 (providing a list of states and the crimes that require arrestees to provide DNA samples in each).

3 See, e.g., State v Raines, 857 A.2d 19, 43 (Md. 2004) (upholding the Maryland DNA Collection Act); Green v. Berge, 354 F.3d 675, 679 (7th Cir. 2004) (upholding the Wisconsin DNA collection law); Groceman v. United States Dep't of Justice, 354 F.3d 411, 413-14 (5th Cir. 2004) (per curiam) (upholding the federal DNA collection law); Velasquez v. Woods, 329 F.3d 420, 421 (5th Cir. 2003) (per curiam) (upholding the Texas DNA collection law); Roe v. Marcotte, 193 F.3d 72, 76-82 (2d Cir. 1999) (upholding the Connecticut DNA collection law); Boling v. Romer, 101 F.3d 1336, 1339-40 (10th Cir. 1996) (upholding the Colorado DNA collection law); Schlicher v. Peters 103 F.3d 940, 943 (10th Cir. 1996) (upholding the Kansas DNA collection law); Jones v. Murray, 962 F.2d 302, 305-08 (4th Cir. 1992), cert. denied, 506 U.S. 977 (1992) (upholding the Virginia DNA collection law). Additionally, some federal district courts have upheld state DNA collection laws. See Padgett v. Ferrero, 294 F. Supp. 2d 1338, 1342-44 (N.D. Ga. 2003) (upholding the Georgia DNA collection law); Kruger v. Erickson, 875 F. Supp. 583, 588-89 (D. Minn. 1995) (upholding the Minnesota DNA collection law).

See supra note 2 (listing examples of crimes that require DNA sampling for arrestees according to federal law).

$5 \quad$ For cases upholding the DNA testing of arrestees to the Supreme Court's decision in Maryland v. King (King II), 133 S. Ct. 1958 (2013), see United States v. Mitchell, 652 F.3d 387, 415-16 (3rd Cir. 2011) (en banc); United States v. Pool, 621 F.3d 1213, 1228 (9th Cir. 2010), vacated on other grounds 659 F.3d 761 (9th Cir. 2011); Mario W. v. Kaipio, 281 P.3d 476, 482-83 (Az. 2012); Haskell v. Brown, 677 F. Supp. 2d 1187, 1189-90 (N.D. Ca. 2009); and Anderson v. Virginia, 650 S.E.2d 702, 706-08 (Va. 2007). For cases invalidating such testing, see Friedman v. Boucher, 580 F.3d 847, 860 (9th Cir. 2009); United States v. Purdy, 2005 WL 3465721 (D. Neb. 2005); People v. Buza, 129 Cal. Rptr. 3d 753, 782 (2011), review granted and opinion superseded by 262 P.3d 854 (Cal. 2011); and King v. Maryland (King I), 42 A.3d 549, 580-81 (Md. 2012).

6 See King II, 133 S. Ct. at 1968 (scrutinizing a Maryland statue regarding the constitutionality of DNA testing). 
The Court decided in Maryland $v$. King (King II) that DNA testing of arrestees and the use of the samples obtained by those tests to identify the subjects of the testing and to link them to other criminal activity does not violate the Fourth Amendment. ${ }^{7}$ Unfortunately, the Court's justification for this conclusion focused primarily on the use of the samples to identify the arrestee, specifically to make sure that the person under arrest was either who he claimed to be or was shown to be through fingerprint comparison. ${ }^{8}$ While identification is one purpose of DNA testing, law enforcement generally acknowledges that the most valuable use of DNA samples is to compare them with samples found at the scenes of serious crimes. ${ }^{9}$ Such a comparison helps solve unsolved crimes, leads to the arrest and conviction of those responsible for such crimes and the exoneration of those who may have been wrongfully charged or convicted. ${ }^{10}$ The Court in King II spent comparatively little time on the constitutionality of this vital purpose for DNA testing and either omitted or responded without sufficient depth to many of the arguments that had been raised in opposition to DNA testing of arrestees. ${ }^{11}$ As such, the opinion in King II was somewhat disingenuous. This disingenuousness provided fodder for critics of this DNA testing such as Justice Scalia, whose dissent in King II mocked the Court's emphasis on identification as the purpose of the testing. ${ }^{12}$

The overall failure of the Court to respond to arguments raised by lower courts and commentators to DNA testing of arrestees is particularly unfortunate because there are persuasive responses to those arguments and sound reasoning why such testing complies with the Fourth Amendment. ${ }^{13}$ The arguments advanced by opponents of DNA testing of arrestees fall basically into two categories. ${ }^{14}$ The first category relates to the presumption of innocence. ${ }^{15}$ In distinguishing between the DNA testing of those already convicted of crimes, and those who have only been arrested, some courts and commentators have emphasized 
Valparaiso University Law Review, Vol. 49, N0. 3 [2015], Art. 8

that the latter group of individuals is bathed in the presumption of innocence. ${ }^{16}$ While this is certainly the case, this Article argues that the principles related to the presumption have little, if any, relevance to the constitutionality of DNA testing of arrestees. ${ }^{17}$

The second category of arguments advanced in opposition to the DNA testing of arrestees revolves around the criteria adopted by the Supreme Court to assess the legality of government intrusions into areas protected by the Fourth Amendment when there is no individualized suspicion that would justify a search or seizure. ${ }^{18}$ These arguments focus on the balancing test the Court uses in such searches and seizures - that is, analyzing the extent of the government intrusion involved and balancing it against the societal need to conduct such intrusions. ${ }^{19}$ This Article will posit that when the statute enabling the DNA testing of arrestees is limited in scope, as is the Maryland statute at issue in King II, the benefits to be achieved by such testing outweigh the minor intrusion to the arrestees. ${ }^{20}$ The other argument regarding searches and seizures without individualized suspicion relies on previous decisions of the Supreme Court which held some such suspicionless searches to be in violation of the Fourth Amendment if their primary purpose was to ferret out evidence of a crime rather than achieve some other societal benefit. ${ }^{21}$ This Article demonstrates that such holdings are inconsistent, confusing, and incompatible with the principles on which the Fourth Amendment is based.22

Additionally, an important factor in the Court's application of the balancing test has been whether the subject of the search or seizure has a diminished expectation of privacy. ${ }^{23}$ The Court has given greater latitude to government agencies to conduct intrusions into areas normally considered protected by the Fourth Amendment when the targets of those searches or seizures have a diminished expectation of privacy. ${ }^{24}$ Those who are arrested and placed in full custodial facilities,

\footnotetext{
See infra Part IV (conveying the constitutional argument against DNA sampling).

See infra Part IV (elaborating on the presumption of innocence).

King II, 133 S. Ct. at 1981.

See infra Part V.A.1-3 (discussing the extent of intrusion of DNA testing); see also Wyoming v. Houghton, 526 U.S. 295, 300 (1999) (describing the balancing test and how it is applied to cases).

20 See infra Part VI (demonstrating the several crimes that have been solved because of DNA testing).

21 See infra notes 352-62 and accompanying text (discussing the "closely regulated

business doctrine," which allows states to address social problems by both an administrative scheme and thorough penal sanctions).

22 See infra Part V.A.1-3 (advancing arguments surrounding DNA testing).

See infra Part VI (addressing privacy expectations).

See infra Part VI (assessing an arrestee's diminished expectation of privacy).
} 
such as jails, have a significantly diminished expectation of privacy and therefore are more susceptible to certain intrusions on their Fourth Amendment rights, especially when those intrusions are effected in a non-arbitrary manner. ${ }^{25}$

DNA testing has played an important role in leading to the release and even exoneration of an increasing number of those who have been convicted of serious crimes. ${ }^{26}$ For various reasons, prosecutors have often argued, often successfully, against obtaining DNA samples from those convicted of crimes and comparing them to the samples found at other crime scenes. ${ }^{27}$ This opposition is for the most part unfortunate, as defense attorneys and various innocence projects have successfully used these results to demonstrate the innocence of those convicted of serious crimes, or at least show a reasonable doubt of a convicted individual's guilt. 28

There is something to be said for the notion that because DNA science has been shown to be reliable when the testing process is done correctly, its use should be maximized with respect to insuring that the right perpetrators are convicted as often as possible for any crime where DNA evidence is available. Unless absolutely necessary, there should be as few barriers as possible to the use of such critical evidence by prosecutors or defendants. In our constitutional system, a goose and gander argument such as this one, has its limits. Regardless of the probative value of certain evidence, if the government obtains it through means prohibited by constitutional protections, such as those embodied in the Fourth, Fifth, and Sixth Amendments, the evidence should not be available to the government. ${ }^{29}$ To some extent, this conclusion leads in a

25 See infra Part V.A.3 (expressing concern that searches without individualized suspicion that are conducted at the discretion of officers may be arbitrary).

26 See infra Part V.B (explaining the second step in the reasonableness balancing test which looks at the nature of the government interest).

27 See Shaila Dewan, Prosecutors Block Access to DNA Testing for Inmates, N.Y. TIMES (May 17, 2009), available at http:// www.nytimes.com/2009/05/18/us/18dna.html? pagewanted= all\&_r=1\&, archived at http://perma.cc/6CSK-SPJD (reporting on DNA exonerations). In 2009, the New York Times reported that:

A recent analysis of 225 DNA exonerations by Brandon L. Garrett, a professor at the University of Virginia School of Law, found that prosecutors opposed DNA testing in almost one out of five cases. In many of the others, they initially opposed testing but ultimately agreed

Id. to it. In 98 of those 225 cases, the DNA test identified the real culprit.

28 See infra Part V.B (explaining that the second step of the reasonableness balancing test evaluates the nature of the government interest).

29 See generally U.S. CONST. amends. IV-VI (providing the text of the aforementioned amendments, including the right against search and seizure, the right against selfincrimination, and the right to a public and speedy trial). 
circular manner back to the original assessment of whether DNA testing of arrestees violates constitutional protections. ${ }^{30}$ That is not to say, however, that either society or the courts should minimize the benefits to be achieved by enhancing the likelihood of convicting the guilty and exonerating the innocent.

Part II of this Article provides a brief description of the science of DNA testing as it is used in the criminal justice system. ${ }^{31}$ Part III discusses the Supreme Court's decision in King II. ${ }^{32}$ Part IV addresses the argument of the opponents that DNA testing of arrestees violates the presumption of innocence. ${ }^{33}$ The chief focus of the Article appears in Parts V, VI, and VII, which responds to the arguments posed by those who claim such testing violates the Fourth Amendment. ${ }^{34}$ Part V addresses the balancing test for such searches and seizures long employed by the Supreme Court. ${ }^{35}$ Parts VI and VII describe and critique the use of the primary purpose test as an important factor in determining whether the Fourth Amendment has been violated. ${ }^{36}$ This test looks to whether the primary purpose of the government's search or seizure was something other than to ferret out ordinary criminal wrongdoing, and only in such situations excuses the absence of individualized suspicion. ${ }^{37}$

In advocating a method to apply the Fourth Amendment in a manner that is both more consistent than the current approach and more faithful to the principles of the Fourth Amendment, this Article analyzes the constitutionality of DNA testing of arrestees for the purpose of using those results to compare with DNA found at the scenes of serious crimes. ${ }^{38}$ This analysis leads to the conclusion that such government conduct complies with the reasonableness test of the Fourth Amendment and other constitutional protections when such testing is done pursuant to statutes that remove arbitrariness and limit the use of the DNA

\footnotetext{
See infra Parts V-VII (conducting a constitutional analysis of DNA testing arrestees).

See infra Part II (introducing DNA testing).

See infra Part III (including a case discussion of Maryland v. King).

See infra Part IV (discussing an arrestee's presumption of innocence).

See infra Parts V \& VI (explaining both the balancing test for reasonableness and the diminished expectation of privacy).

35 See infra Part V (including a discussion of the balancing test for reasonableness, which focuses on the extent of the intrusion).

36 See infra Parts VI \& VII (providing explanation of the diminished expectation of privacy and the primary purpose test).

37 See infra notes 352-62 and accompanying text (discussing the "closely regulated business doctrine," which allows states to address social problems by both an administrative scheme and thorough penal sanctions).

38 See infra Part V.B (elaborating on the use of DNA evidence to solve other crimes).
} 
samples. ${ }^{39}$ More broadly, this Article critiques some of the ways in which the diminished expectation of privacy rationale and the primary purpose doctrine have been used by the Supreme Court in assessing the constitutionality of searches and seizures performed without individualized suspicion.

\section{TESTING OF DNA}

"Deoxyribonucleic acid ("DNA") is a complex molecule contained within each nucleated cell of the human body... [that] provides a complete blueprint for the human being." 40 During reproduction, chromosomes from the mother and father combine to create a new and unique genetic structure. ${ }^{41}$ With the exception of identical twins, no two individuals have identical DNA. ${ }^{42}$ DNA testing can determine the variations of DNA structure in each individual. ${ }^{43}$

DNA collection for comparison purposes in criminal cases is done in one of two primary ways. First, it may be accomplished by drawing blood. ${ }^{44}$ Currently the FBI collects blood by a finger-prick. ${ }^{45}$ Second, it may be done by rubbing two cotton swabs up and down the inside of each of the suspect's cheeks with enough pressure to remove cells. ${ }^{46}$ If necessary, reasonable force may be used to obtain a DNA sample. ${ }^{47}$ Samples are sent to the appropriate laboratory for testing. ${ }^{48}$ The samples are then analyzed in accordance with FBI standards and CODIS requirements. ${ }^{49}$ CODIS, or the Combined DNA Index System, blends forensic science and computer technology by storing DNA profiles at the local, state, and national level. ${ }^{50}$ Data stored at the national level is kept

\footnotetext{
See infra Part VIII (advancing the constitutionality of DNA testing).

8 AM. JUR. 3d, Foundation for DNA Fingerprint Evidence $§ 3$ (1990 \& Supp. 2014). include the use of buccal swabs); MARCUS L. BROWN ET AL., GUIDELINES FOR SUBMITTING PHYSICAL EVIDENCE 22 (2012), available at https://www.mdsp.org/LinkClick.aspx? fileticket=UUXGHnwBnBs\%3D\&tabid=429\&mid=1122, archived at https: $/ /$ perma.cc $/ 3$ JKF-

$47 \quad 28$ C.F.R. $\S 28.12(d)$ (2011); MD. CODE REGS. § 29.05.01.04(C) (2011).

$48 \quad 28$ C.F.R. $\S 28.12(\mathrm{f})(2)(2011) ;$ MD. CODE REGS. $\$ 29.05 .01 .04(\mathrm{D})(2011)$.

$49 \quad 28$ C.F.R. § 28.13 (2011); MD. CODE REGS. § 29.05.01.04(A) (2011).

50 What is CODIS?, NAT'L INST. JUST. (July 16, 2010), available at http://www.nij.gov/ journals/266/Pages/backlogs-codis.aspx, archived at http:/ / perma.cc/93ER-WE86.
} TCC2. 
Valparaiso University Law Review, Vol. 49, N0. 3 [2015], Art. 8

in the National DNA Index System, or NDIS. ${ }^{1}$ CODIS was designed to compare a target DNA record against the DNA records contained in the database. ${ }^{52}$ If a match is identified by CODIS, the laboratories involved in the match exchange information to verify the match and establish coordination between the two agencies. ${ }^{53}$

DNA analysis is done by using a Polymerase Chain Reaction ("PCR") to amplify the DNA strands and analyze Short Tandem Repeats ("STRs"). ${ }^{54}$ Specifically, the analysis focuses on thirteen core STRs. ${ }^{55}$ Analysis of these strands reveals the combinations of uniquely paired protein bases within the human genome which may be used to match the DNA taken from an individual to the DNA left at a crime scene. ${ }^{56}$ The thirteen STR strands are referred to as "junk sites" because they are not associated with any physical or medical characteristics. ${ }^{57}$

Numerous steps have been taken by law enforcement agencies to assure that DNA testing will not reveal private information about the subject of the testing while assuring accurate results. ${ }^{58}$ To ensure that the DNA profile of a convicted offender will not be disclosed, Congress and many states have passed statutory rules, which provide that DNA samples and analyses may only be used for identification purposes. ${ }^{59}$ Further, the thirteen "junk sites" were specifically selected for analysis because they do not control or influence the expression of any trait.60 This manner of DNA analysis does not reveal information relating to medical conditions or other traits. ${ }^{61}$ Indeed, the system provides a "genetic fingerprint, which uniquely identifies an individual, but does

$51 \quad I d$.

52 CODIS and NDIS Fact Sheet, FBI, available at http://www.fbi.gov/about-us/lab/ biometric-analysis/codis/codis-and-ndis-fact-sheet (last visited Apr. 13, 2015), archived at http:/ / perma.cc/KX2S-Q4A3 [hereinafter CODIS and NDIS Fact Sheet].

53 Id.

54 See supra note 46 and accompanying text (discussing buccal swabs as an appropriate method for collecting DNA samples).

$55 \quad$ Mary McCarthy, Am I My Brother's Keeper?: Familial DNA Searches in the Twenty-First Century, 86 Notre DAme L. ReV. 381, 384 (2011).

56 Id. There are literally trillions of different possible base pair combinations. Id.

57 H.R. REP. NO. 106-900(I), at 27 (2000).

58 See, e.g., MD. CRIM. PROC. § 8-201 (2009) (listing the procedure necessary to get a DNA sample).

5942 U.S.C. § 14132(b)(3) (2006); MD. CODE ANN., PUB. SAFETY, § 2-505(b)(1) (2011); CAL. PENAL CODE $§ 295.1$ (West 2012); see VA. CODE ANN. §§ 19.2-310.2-3 (West 2012) (stating that DNA shall be analyzed "to determine identification characteristics"); N.J. STAT. ANN. § 53:1-20.21 (West 2012) (permitting DNA testing for law enforcement identification or other non-intrusive purposes).

60 See McCarthy, supra note 55, at 384 (explaining what information is contained in a strand of DNA).

$61 \quad I d$. 
not provide a basis for determining or inferring anything else about the person." 62 Additionally, under federal and several state statutes, no names or other personal identifiers are stored with the DNA analysis, and access to the records is limited to ensure confidentiality. ${ }^{63}$ Most statutes require that DNA records be destroyed or expunged if the criminal action does not result in a conviction, a conviction is reversed, or if the individual is granted an unconditional pardon. ${ }^{64}$ Finally, failure to properly expunge DNA records or to otherwise comply with privacy requirements can result in fines and/or imprisonment. ${ }^{65}$

It is extremely unlikely for DNA testing to result in false positive identifications and comparisons. ${ }^{66}$ When analyzing the thirteen STRs, the probability of a random match of DNA evidence found at a crime scene and a DNA sample are between one in a billion and one in a quadrillion.67 Thus, DNA testing can identify an individual with more than $99 \%$ accuracy. 68

The reliability of DNA testing is an important factor when using the balancing test employed by courts to determine if a search or seizure performed without some degree of individualized suspicion meets the requirements of the Fourth Amendment. ${ }^{69}$ As discussed in Part V, one factor in that test is the importance of the government need to conduct

62 Id.; see also CODIS and NDIS Fact Sheet, supra note 52 (discussing the purpose of CODIS and NDIS).

63 See MD. CODE ANN., Pub. SAFETY, § 2-511(a)(1) (2011) (providing a state statute that discusses the identifying information available from DNA testing); CAL. PENAL CODE $\S \S 299.5-299.7$ (West 2012) (explaining the identifying information made available by DNA samples); VA. CODE ANN. § 19.2-310.6 (West 2012) (providing federal and state statutes regarding the identifying information DNA samples make available).

64 Md. Code Ann., Pub. Safety, § 2-511(a)(1); Cal. Penal Code § 299; VA. Code AnN. § 19.2-310.7; N.J. STAT. ANN. § 53:1-20.25 (West 2012).

65 Md. Code AnN., Pub. SAfety, § 2-512 (2011); VA. Code ANN. § 19.2-310.7; N.J. Stat. ANN. § 53:1-20.26. All of these statutes relay the penalty for disclosing information in the DNA database. Anyone who intentionally and wrongfully discloses information in the DNA database is guilty of a disorderly person offense, which is a misdemeanor that can carry a prison sentence of up to six months. See N.J. STAT. ANN. § 2C:43-8 (demonstrating the increased jail time for disorderly conduct).

${ }_{66}$ See BROWN ET AL., supra note 46 (advancing the rarity of a false positive).

$67 \quad I d$.

68 See Randy James, A Brief History of DNA Testing, TIME (June 19, 2009), available at http://www.time.com/time/nation/article/0,8599,1905706,00.html, archived at http:// perma.cc/FGN7-FZUU (discussing the growth of DNA testing since it began in 1985 and how now, forensic testing can determine distinctive patterns in DNA with 99\% accuracy); see also MD. CRIM. PROC. § 8-201 (2011) (codifying the Maryland statute that covers DNA testing and the preservation of scientific evidence).

69 See infra Part V.B (demonstrating that reliability supports a strong government interest argument). 
Valparaiso University Law Review, Vol. 49, N0. 3 [2015], Art. 8

such an intrusion..$^{70}$ Because DNA testing is so reliable, it can play a major role in linking an arrestee to a serious crime or a definitive role in exonerating someone of that crime. ${ }^{71}$ The government interest in conducting such testing is therefore quite substantial.

\section{MARYLAND V. KING}

In 2009, Alonzo King was arrested in Maryland for the crime of assault in the first degree. ${ }^{72}$ Under a Maryland statute providing for the DNA testing of those about to be detained after being charged with certain felonies, King had a sample of his DNA taken. ${ }^{73}$ The process used to obtain the sample involved swabbing King's cheek with a cotton cloth. ${ }^{74}$ The sample was then entered into CODIS. ${ }^{75}$ After comparative analysis, King's sample was found to match the DNA found at the scene of a 2003 rape. ${ }^{76}$ Based in part on this sample and another DNA sample of King taken later, which also matched the DNA at the rape scene, King was subsequently indicted and convicted of rape. ${ }^{77}$ The Maryland Court of Appeals overturned King's conviction holding that the part of the statute authorizing the taking of DNA samples from arrestees violated the Fourth Amendment. ${ }^{78}$ As both federal and state courts were divided

\footnotetext{
70 See infra Part V.A (discussing the extent of intrusion of DNA testing).

71 See infra Part VI (illustrating the importance of DNA in both acquittals and convictions).

72 See Maryland v. King (King II), 133 S. Ct. 1958, 1965 (2013) (describing the nature of King's crime).

73 See MD. CODE ANN., Pub. SAFety § 2-504(a)(i) (2009) (requiring that an "individual convicted of a felony or a violation of $\S 6-205$ or $§ 6-206$ of the Criminal Law Article shall have a DNA sample collected either at the time of sentence or on intake to a correctional facility, if the individual is sentenced to a term of imprisonment"); see also King II, $133 \mathrm{~S}$. Ct. at 1966 (providing that booking personnel used a sample from King's cheek pursuant to the provision of the Maryland DNA Collection act).

$74 \quad$ King II, 133 S. Ct. at 1965.

75 See supra Part II (discussing the testing of DNA and what the testing process entails); see also King II, 133 S. Ct. at 1968 (providing that the Combined DNA Index system was authorized by Congress and supervised by the Federal Bureau of Investigation). The CODIS system connects DNA laboratories at the local, state, and national level. Id.

76 King II, 133 S. Ct. at 1968 (providing that King's identification as the rapist was in part a result of a national project to standardize the collection and storage of DNA profiles).

77 See id. at 1965 (stating that the DNA taken from King was found to match the DNA taken from the 2003 Salisbury rape victim and that as a result of the match, King was tried and convicted of rape).

78 See King v. Maryland (King I), 42 A.3d 549, 555-56 (Md. 2012) (holding that the Maryland DNA Collection act is unconstitutional under the Fourth Amendment totality of the circumstances balancing test).
} 
over the constitutionality of such procedures, the Supreme Court granted certiorari in King II.79

After describing the process by which DNA is taken and tested, the reliability of the results and the specifics of the Maryland statute, the Court turned to the critical issue of whether the search and seizure of the DNA sample satisfied the test for reasonableness under the Fourth Amendment. ${ }^{80}$ As the Court notes, this test requires balancing the extent of the government's interest in the procedure against the degree of intrusion to the individual. ${ }^{81}$ The Court asserted that the primary interest of the government consisted of establishing the identity of the arrestee and obtaining the important benefits that flow from verifying this identity. ${ }^{82}$ First, the Court alluded to the importance of identifying arrestees to reveal their "public persona" and thus let the police know their criminal history. ${ }^{83}$ Comparing this purpose to the taking of fingerprints, the Court said the only difference between DNA samples and other means of establishing identity is the "unparalleled accuracy" of DNA results. ${ }^{84}$ The Court then discussed the need to know who the arrestee is and his criminal history. ${ }^{85}$ This is necessary to determine where and under what conditions the arrestee should be housed, to inform the decision about how dangerous the individual is, and what, if any, bail is needed to insure his appearances in court.86 Finally, and unfortunately with minimal analysis, the Court credited the use of DNA

79 See King II, 133 S. Ct. at 1965 (providing that the Court of Appeals of Maryland ruled that the DNA taken from King's booking was an unreasonable search of the person).

80 See id. at 1968-69 (describing that even though the DNA swab procedure presents an issue that has not yet been before the Court, the framework for deciding the issue is well established under the Fourth Amendment).

$81 \quad I d$. at 1970 (quoting Wyoming v. Houghton, 526 U.S. 295, 300 (1999)); see infra Part V.A.1 (analyzing the balancing test for reasonableness under the Fourth Amendment, focusing on physical intrusions).

82 See King II, 133 S. Ct. at 1970 (addressing the fact that the legitimate government interest served by collecting the DNA is that law enforcement officers must identify the persons they take into custody); infra Part VII (providing information regarding the primary purpose test and how it relates to the DNA testing of arrestees).

83 See King II, 133 S. Ct. at 1972 (providing that the data found in official records is used to produce a comprehensive record of the suspect's criminal history); infra Part VII (assessing the primary purpose test and how it relates the DNA testing of arrestees).

84 See King II, 133 S. Ct. at 1964 (stating that there is an unparalleled accuracy that DNA provides).

85 See id. at 1971 (discussing that identity encompasses more than simply the name of an arrestee); see also Hiibel v. Sixth Judicial Dist. Court of Nevada, 542 U.S. 177, 192 (2004) (stating that in every criminal case it is necessary to know who has been arrested and who is being tried); infra Part VII (assessing the primary purpose test and how it relates the DNA testing of arrestees).

86 See King II, 133 S. Ct. at 1971-74 (providing that a name holds little value in comparison to the interest in identifying an individual brought into custody). 
Valparaiso University Law Review, Vol. 49, N0. 3 [2015], Art. 8

testing with helping to exonerate people who have been wrongly imprisoned for crimes. ${ }^{87}$ In such circumstances, presumably a DNA sample of an arrestee would indicate it was he who committed the crime for which the wrong person was imprisoned. ${ }^{88}$

The Court weighed what it regarded as a significant government interest against the extent of the intrusion resulting from DNA testing. ${ }^{89}$ It concluded that the physical intrusion caused by the swabbing of the cheek is minor and the privacy intrusion involved was sufficiently minimal due to the provisions of the Maryland statute limiting the use of the results. ${ }^{90}$ When combined with the diminished expectation of privacy of one arrested based on probable cause of having committed a serious crime and about to be confined to a custodial institution, this intrusion was, according to the Court, outweighed by the government's needs to conduct the testing. ${ }^{91}$

Writing in dissent, Justice Scalia, speaking for four justices, said an integral part of the Fourth Amendment is that no government searches

87 See id. at 1974 (discussing that in the interest of justice, the identification of an arrestee may have the effect of freeing a person wrongfully convicted). Andrea Roth states in her article:

One might be forgiven, then, for predicting that an opinion upholding that law would be an unapologetic paean to the crime-solving virtues of DNA databases. Yet the five-member King majority devotes only two sentences to the ability of DNA to solve crimes, and even then, the mention is simply of the "salutary effect of freeing a person wrongfully imprisoned" for an offense linked to an arrestee through a database hit. Instead of justifying Maryland's law as a reasonable crime-fighting measure, the majority reconceptualizes the law as deploying DNA typing as a "routine booking procedure" and focuses exclusively on the state's interest in confirming arrestees' identities and determining arrestees' criminal history before making bail decisions.

Andrea Roth, Maryland v. King and the Wonderful, Horrible DNA Revolution in Law Enforcement, 11 OHIO ST. J. CRIM. L. 295, 296 (2013).

88 See King II, 133 S. Ct. at 1974 (discussing that in the interest of justice, the identification of an arrestee may have the effect of freeing a person wrongfully convicted).

89 See id. at 1977 (comparing the intrusion of the DNA sample to the substantial governmental interest); infra Part V.A.1 (examining the balancing test for reasonableness under the Fourth Amendment focusing on the extent of the physical intrusion).

90 See King II, 133 S. Ct. at 1979 (providing that a buccal swab does not increase the indignity of the circumstances surrounding an arrest); see also infra Part V.A.1 (analyzing the balancing test for reasonableness under the Fourth Amendment focusing on the extent of the physical intrusion).

91 See King II, 133 S. Ct. at 1980 (stating that there are significant state interests in identifying an individual who is taken into custody); see also infra Part V.B (examining the balancing test for reasonableness under the Fourth Amendment focusing on the nature of the government interest); Lauren Deitrich, Comment, Say Aaah! Maryland v. King Defines Reasonable Standard for DNA Searches, 49 VAL. U. L. REV. 1095, 1097-99 (2015) (discussing the reasonableness of an individual's diminished expectation of privacy). 
for evidence of a crime can take place without some form of prior suspicion. ${ }^{92}$ He asserted that the only time the Court had previously permitted such searches or seizures was when the primary purpose of the government intrusion was other than ordinary crime investigation. ${ }^{93}$ Justice Scalia then went on to criticize the Court's effort to distinguish the purpose of DNA testing from ordinary criminal investigation by the Court's characterization of this purpose as "identification." 94 He argued that much of what a criminal investigation often involves is identification-the issue involved here-when comparing the DNA sample of King to that found at the rape scene to determine if he was the perpetrator of that crime. ${ }^{95}$ Justice Scalia then mocked the Court's claim that the DNA samples were necessary to a quick identification of arrestees. ${ }^{96}$ He did so primarily by showing that both the language in the enabling statute regarding the purpose for taking the samples and the lengthy process by which King's DNA sample was taken and tested rebut this assertion. ${ }^{97}$ Finally, with respect to the Court's comparison of the use of DNA samples and that of fingerprints, Justice Scalia argued that criminal investigation is the primary purpose of obtaining DNA samples whereas "fingerprints of arrestees are taken primarily to identify them (though that process sometimes solves crimes)." 98 The

92 See King II, 133 S. Ct. at 1980 (Scalia, J., dissenting) (illustrating that the Fourth Amendment forbids searching a person when there is no basis for believing that the person is guilty of a crime); infra text accompanying notes 93-99 (analyzing Justice Scalia's dissent).

93 See King II, 133 S. Ct. at 1981-82 (stating there are instances where the Court has permitted searches without individualized suspicion, however, none of those cases include a search with the primary purpose of detecting criminal wrongdoing); infra Part V.A.1 (scrutinizing the balancing test for reasonableness under the Fourth Amendment focusing on the extent of the physical intrusion).

94 See King II, 133 S. Ct. at 1982-83 (providing that the Court elaborated ways that the DNA search served the special interest of identifying King, but instead the purpose of the search was to look for evidence that King committed crimes unrelated to his arrest); infra Part V.A.1 (assessing the balancing test for reasonableness under the Fourth Amendment focusing on the extent of the physical intrusion).

95 See King II, 133 S. Ct. at 1982-83 (elaborating on the ways that the DNA search served the special interest of identifying King). The Court also posed that the purpose of the search was to look for evidence that King committed crimes unrelated to his arrest. Id.

$96 \quad I d$.

$97 \quad$ Id. at 1983.

98 Id. at 1987. The distinction Justice Scalia draws between the purposes of taking fingerprints from arrestees and taking their DNA is a dubious one. $I d$. He argues that that the primary purpose of taking such fingerprints is to identify the arrestee and apparently these samples just happen to solve crimes as well. King II, $133 \mathrm{~S}$. Ct. at 1982-83. This minimizes the fact both that "fingerprinting is one the oldest methods of investigating a crime using science" and that "fingerprints have been the reason for the solving of a vast amount of cases." How Fingerprinting Improves Criminal Investigations, PORTLAND ST. U., available at http://online.ccj.pdx.edu/resources/news-article/how-fingerprinting- 
Valparaiso University Law Review, Vol. 49, N0. 3 [2015], Art. 8

remainder of this Article addresses the issues discussed in King II and others that were either offered minimal treatment or not directly addressed in the holding. ${ }^{99}$

\section{PRESUMPTION OF INNOCENCE}

One argument that has been made against the DNA testing of arrestees relates to the presumption of innocence.100 States and the federal government have, for some time, been testing convicted felons to determine if their DNA matches the DNA found at crime scenes. ${ }^{101}$ Such testing has been conducted without any requirement that the tested individual is suspected of any other crime.102 Both state and federal courts have almost universally upheld such testing against claims that it violated the Fourth Amendment. ${ }^{103}$ Some have argued that similar testing of those arrested for, but not convicted or not yet convicted of, a felony is distinguishable from the testing of convicted felons because the

improves-criminal-investigations/ (last visited Apr. 14, 2015), archived at http:/ / perma.cc/7Q6A-HLCW; Molly Wolgar et al., Famous Crimes Solved by Fingerprinting, FINGERPRINTS!, available at http:/ / fingerprintinggsc.weebly.com/famous-crimes-solved-byfingerprinting.html (last visited Apr. 14, 2015), archived at http:/ / perma.cc/BSB4-29V4.

99 See infra Parts IV-VII (discussing such sections as the presumption of innocence, balancing test for reasonableness, the diminished expectation of privacy, and the primary purpose test).

100 See infra Part IV (elaborating on this presumption).

101 See generally CODIS and NDIS Fact Sheet, supra note 52 (discussing the process after matching DNA with evidence from another crime scene).

102 See infra notes 148-58 and accompanying text (providing that the collection of DNA samples is also used for solving unrelated crimes).

103 David H. Kaye, The Genealogy Detectives: A Constitutional Analysis of "Familial Searching", 50 AM. CRIM. L. REV. 109, 130 (2013); see State v. Raines, 857 A.2d 19, 26 (Md. 2004) ("[E]very other appellate court we have found dealing with the issue [of DNA collection] has upheld the DNA collection statute at issue before it."); see also Green v. Berge, 354 F.3d 675, 677-79 (7th Cir. 2004) (upholding the Wisconsin DNA collection law); Groceman v. U.S. Dep't of Justice, 354 F.3d 411, 413-14 (5th Cir. 2004) (per curiam) (upholding the federal DNA collection law); United States v. Kimler, 335 F.3d 1132, 1146 (10th Cir. 2003) (upholding the federal DNA collection law); Velasquez v. Woods, 329 F.3d 420, 421 (5th Cir. 2003) (per curiam) (preserving the Texas DNA collection law); Roe v. Marcotte, 193 F.3d 72, 79-80 (2d Cir. 1999) (holding that a DNA statute is constitutional); Shaffer v. Saffle, 148 F.3d 1180, 1181-82 (10th Cir. 1998) (upholding the Oklahoma DNA collection law); Schlicher v. Peters, 103 F.3d 940, 943 (10th Cir. 1996) (upholding the Kansas DNA collection law); Boling v. Romer, 101 F.3d 1336, 1339-40 (10th Cir. 1996) (upholding the Colorado DNA collection law); Jones v. Murray, 962 F.2d 302, 305-08 (4th Cir. 1992) (upholding a Virginia DNA collection law). For some federal district courts that have also upheld state DNA collection laws, see Padgett v. Ferrero, 294 F. Supp. 2d 1338, 1342-44 (N.D. Ga. 2003), upholding the Georgia DNA collection law, and Kruger v. Erickson, 875 F. Supp. 583, 588-89 (D. Minn. 1995), upholding the Minnesota collection law. 
former group is protected by the presumption of innocence.104 In fact, the Maryland Court of Appeals decision that was later overturned by the Supreme Court used part of this reasoning in its opinion invalidating the DNA testing of arrestees. ${ }^{105}$

In assessing whether the presumption of innocence should act as a barrier against the DNA testing of arrestees, one must look at the meaning of the presumption and its connection, if any, to the Fourth Amendment and specifically to the expectation of privacy that has come to define "search."106 The Supreme Court defined this well-known and accepted principle of American criminal justice as follows-" $[\mathrm{t}] \mathrm{he}$ presumption of innocence is a conclusion drawn by the law in favor of the citizen, by virtue whereof, when brought to trial upon a criminal charge, he must be acquitted, unless he is proven to be guilty."107 The presumption has been applied to various aspects of the criminal trial such as the burden on the prosecution to prove the defendant guilty beyond a reasonable doubt at trial and the nature of the instructions given to the jury at the end of the trial. ${ }^{108}$

The determination regarding the DNA testing of arrestees, however, involves issues entirely independent of the above enumerated concerns and protections. ${ }^{109}$ The questions that arise regarding the constitutionality of such testing relate to whether the search, seizure, and use of the arrestee's DNA are reasonable under the Fourth Amendment. ${ }^{110}$ Such reasonableness determinations balance the extent and nature of the governmental intrusion against its need and

104 People v. Buza, 129 Cal. Rptr. 3d 753, 755 (Cal. Ct. App. 2011), review granted and opinion superseded, 262 P.3d 854 (Cal. 2011); see Mario W. v. Kaipio, 228 Ariz. 207, 222 (Ct. App. 2011), vacated, 281 P.3d 476 (2012) (Norris, J., dissenting) (arguing that there is a presumption of innocence and that the state failed to justify why it is entitled to invade the reasonable expectation of privacy).

105 King v. Maryland (King I), 42 A.3d 549, 576 (Md. 2012) (reasoning that if the application of the balancing test of the Fourth Amendment results in a close call when considering convicted felons, then the balance must tip in favor of the closely held belief of the presumption of innocence).

106 Katz v. United States, 389 U.S. 347, 515 (1967) (holding that the government agents in the case ignored the procedure of antecedent justification). But see United States v. Jones, 132 S. Ct. 945, 948 (2012) (including a discussion of the trespass doctrine); Florida v. Jardines, 133 S. Ct. 1409, 1417 (2013) (adding government intrusions that constitute trespasses undertaken for investigative purposes to the definition of search).

107 Coffin v. United States, 156 U.S. 432, 459 (1895).

108 Id.

109 Id.; see Maryland v. King (King II), 133 S. Ct. 1958, 1969 (2013) (expanding the inquiry to focus on reasonableness).

110 See King II, 133 S. Ct. at 1969 (providing that the ultimate measure of constitutionality is reasonableness). 
Valparaiso University Law Review, Vol. 49, N0. 3 [2015], Art. 8

importance.111 A critical element in assessing the extent of the intrusion is a consideration of the expectation of privacy that the subject of the intrusion has at the moment the search or seizure is executed.112 As discussed below, one's status in a total custody facility substantially diminishes his or her expectation of privacy and, as decisions of the Supreme Court involving the rights of inmates detained in custodial institutions have made clear, the presumption of innocence in no way informs a decision about whether the particular government policy or procedure being challenged complies with the Fourth Amendment. ${ }^{113}$

In Bell v. Wolfish, the plaintiffs claimed constitutional violations stemming from certain conditions of confinement at a New York facility designed primarily to house pre-trial detainees. ${ }^{114}$ The Court noted that such detainees maintain certain constitutional rights, although diminished, but then uttered a definitive statement regarding the relevance of the presumption of innocence to any assessment of these rights. ${ }^{115}$ After describing the purposes of the presumption, the Court wrote, "but it has no application to a determination of the rights of a pretrial detainee during confinement before his trial has even begun."116 This is not to say that conviction of a crime plays no role when assessing the expectation of privacy that one has, but only that the presumption of innocence plays no role in that assessment, at least where the subject is one confined in a total custodial environment. ${ }^{117}$ The task then is to see why conviction for a crime may diminish one's expectation of privacy and whether similar factors apply to one who has not been convicted but is in a custodial facility after a criminal arrest.

The issue in Florence v. Board of Chosen Freeholders of the County of Burlington was whether the highly intrusive body search of a man about to become a pre-trial detainee violated his Fourth Amendment

\footnotetext{
111 See id. at 1970 (reasoning that applying traditional standards of reasonableness require that a court weigh the promotion of a government interest and the degree of which the search intrudes on an individual's privacy).

112 See infra Parts V \& VI (analyzing the balancing test of reasonableness under the Fourth Amendment and how it pertains to the diminished expectation of privacy).

113 See Hudson v. Palmer, 468 U.S. 517, 538 (1984) (O'Connor, J., concurring) (discussing that an inmate in custody retains no significant Fourth Amendment interest); see also infra Parts V \& VI (analyzing the balancing test of reasonableness under the Fourth Amendment and how it pertains to the diminished expectation of privacy).

114 See Bell v. Wolfish, 441 U.S. 520, 533 (1979) (providing that the lawsuit was brought as a class action to challenge numerous confinement conditions at the Metropolitan Correctional Center).

115 Id. at 535. "Under the Due Process Clause, a detainee may not be punished to an adjudication of guilt...." Id.

$116 \quad I d$. at 533.

117 See Hudson, 468 U.S. at 538 (delegating lesser rights to those in custody).
} 
constitutional right. ${ }^{118}$ In concluding that Florence's rights were not violated, the Court analyzed the issues relating to the reasonableness of the search under the Fourth Amendment, but never referred to the presumption of innocence as affecting the issues in the case.119 In his dissent, Justice Breyer argued that a proper balancing test requires articulable suspicion to conduct the search because the extent of the intrusion was so substantial. ${ }^{120}$ Interestingly though, as with the majority opinion, Justice Breyer never refers to the presumption of innocence of a pre-trial detainee as having any bearing on the search involved. ${ }^{121}$

Neither in its purpose nor in the application of the principle by the Supreme Court is there a basis for the argument that the presumption of innocence has any bearing on the legality of the taking and the using of DNA samples from detained pre-trial arrestees. ${ }^{122}$

\section{THE BALANCING TEST FOR REASONABLENESS UNDER THE FOURTH AMENDMENT}

\section{A. Extent of Intrusion}

The Supreme Court has long regarded reasonableness as the "touchstone of the Fourth Amendment."123 In assessing the reasonableness of any governmental intrusion conducted without individualized suspicion that falls within the parameters of the Fourth Amendment, the Supreme Court has balanced the extent of the intrusion against the government's need to conduct the search or seizure involved. ${ }^{124}$ Part $\mathrm{V}$ examines the extent of the intrusion that occurs when an arrestee in a custodial facility is subjected to the taking of a DNA

118 See Florence v. Bd. of Chosen Freeholders of the Cnty. of Burlington, 132 S. Ct. 1510, 1513 (2012) (deciding the issue of whether every detainee who will be admitted to the general population may be required to undergo a visual inspection while undressed); infra Part V.A (discussing the balancing test of reasonableness in greater detail).

119 See Florence, 132 S. Ct at 1523 (holding that the government struck a reasonable balance between inmate privacy and the needs of the institution).

120 See id. at 1528 (reasoning that there are strong justifications on both sides of the argument).

121 See id. (illustrating the omission).

122 King v. Maryland (King I), 42 A.3d 549, 582 (Md. 2012) (Barbera, J., dissenting) (providing the majority's stance on King's privacy interest).

123 Ohio v. Robinette, 519 U.S. 33, 39 (1996) (quoting Florida v. Jimeno, 500 U.S. 248, 250 (1991)); see also Shane Crotty, Note, The Aerial Dragnet: A Drone-ing Need for Fourth Amendment Change, 49 VAL. U. L REV. 219, 221 (2014) ("The Amendment codified the sacred common law right to be secure in one's own person, free from arbitrary and oppressive government intrusion.").

124 United States v. Knights, 534 U.S. 112, 119 (2001) (citing Wyoming v. Houghton, 526 U.S. 295, 300 (1999)). 
Valparaiso University Law Review, Vol. 49, No. 3 [2015], Art. 8

sample that is then compared with DNA samples found at crime scenes.125 This examination is based on the factors previously enumerated by the Supreme Court that bear on the extent of a Fourth Amendment intrusion and are relevant to the acquisition and use of DNA samples of arrestees. ${ }^{126}$ These factors include the degree of physical intrusion, the uses to which evidence is put by the government and others, and whether there are safeguards in place to insure that the search or seizure is not conducted arbitrarily. ${ }^{127}$ Additionally, courts have long regarded whether the subject of the search or seizure has a diminished expectation of privacy as a significant factor in assessing the extent of government intrusions. ${ }^{128}$ This examination demonstrates the taking and use of DNA from arrestees is a relatively minor intrusion that complies with the requirements of the Fourth Amendment when the testing is conducted and limited in a manner consistent with previously enumerated values of that amendment.

\section{Physical Intrusion}

Several courts have described the physical intrusion involved in obtaining a DNA sample as minimal. ${ }^{129}$ While it requires entry into the body of the subject, the actual process involves contact that is brief, painless, and absent any level of real embarrassment. ${ }^{130}$ As the Maryland court in King II described it, the general method for obtaining

\footnotetext{
125 See infra Part V (discussing the extent of extrusion).

126 See Safford Unified Sch. Dist. v. Redding, 557 U.S. 364, 370-71 (2009) (discussing the factors); Winston v. Lee, 470 U.S. 753, 761-62 (1985) (providing the factors for reasonableness); Schmerber v. California, 384 U.S. 757, 771-72 (1966) (relaying the factors).

127 See infra Part V.A.1 (analyzing the extent of the physical intrusion); see also infra Part V.A.3 (examining non-arbitrariness).

128 Maryland v. King (King II), 133 S. Ct. 1958, 1977 (2013); State v. Johnson, 813 N.W.2d 1, 9 (Minn. 2012); United States v. Mitchell, 652 F.3d. 387, 407 (3rd Cir. 2011); State v. Ritter, 956 A.2d 1141, 1143 (Vt. 2008); Banks v. United States, 490 F.3d 1178, 1189 (10th Cir. 2007); United States v. Kraklio, 451 F.3d 922, 924 (8th Cir. 2006); Padgett v. Donald, 401 F.3d 1273, 1280 (11th Cir. 2005).

129 See, e.g., King II, 133 S. Ct. at 1977 (demonstrating the intrusion of a cheek swab is a minimal one); Johnson, 813 N.W.2d at 9 (conveying that a buccal swab inside the cheek to acquire a DNA sample is a minimal intrusion); Mitchell, 652 F.3d. at 407 (providing that the act of collecting DNA is minimal); State v. Ritter, 956 A.2d 1141, 1143 (Vt. 2008) (indicating DNA sample taken by buccal swab is a minimal intrusion); Banks, 490 F.3d at 1189 (showing blood and saliva tests impose minimal intrusions); Kraklio, 451 F.3d at 924 (illustrating that obtaining DNA sample involves minimal intrusion); Padgett, 401 F.3d at 1280 (stating that taking prisoners' saliva samples involves a minor intrusion).

130 In approving the drug and alcohol testing of those railway personnel involved in certain accidents, the Court noted the significance of the fact that such testing was conducted "outside a hospital environment and with a minimum of inconvenience or embarrassment." Skinner v. Ry. Labor Execs. Ass'n, 489 U.S. 602, 625 (1989).
} 
the DNA sample is for "the collector to swab up-and-down and rotate a sterile cotton swab on the interior of the cheek in the subject's mouth, with enough pressure to remove cells[; the] process is repeated on the other cheek with a separate cotton swab." 131 When the Supreme Court approved the more intrusive procedure of removing blood through piercing the skin with a hypodermic needle, albeit with probable cause, in Schmerber v. California, it noted that "for most people the procedure involves virtually no risk, trauma[,] or pain."132 When the Court prohibited a bullet removal surgery sought in Winston $v$. Lee, it described the physical intrusion from the surgery as "severe."133 Similarly, in Safford Unified School District Number 1 v. Redding, the Court determined that the reasonableness test of the Fourth Amendment was violated by the strip search of a thirteen-year-old middle school student based on the articulable suspicion that she possessed a prohibited pain pill, and the Court held this way because the intrusion was "embarrassing, frightening and humiliating." 134 When applying the emerging factors from Schmerber, Lee, and Safford to assess the degree of physical intrusion, it is obvious that taking a swab from the interior cheek, the method used often with arrestees and the one used in King II, is far less of a physical intrusion than the taking of blood, surgery to remove bullets, or strip searching a middle school student. 135 Obtaining DNA samples involves no "risk, trauma[,] or pain." 136 While there is some entry into the body when taking a DNA swab from an inner cheek, there is no piercing of skin as when a blood sample is taken. ${ }^{137}$ As one judge put it in comparing the physical nature of the intrusion involved in the taking of blood with that of buccal swabbing for DNA:

If the subcutaneous removal of blood from a person's veins presents only a marginal intrusion into that person's privacy interest, $a$ fortiori the insertion of a cotton swab into a person's mouth is less of an intrusion and fairly characterized as de minimis. Unlike the process of drawing blood, performing a buccal swab

\footnotetext{
131 King v. Maryland, 42 A.3d 549, 553 n.5 (Md. 2012).

132 Schmerber v. California, 384 U.S. 757, 771 (1966).

133 Winston v. Lee, 470 U.S. 753, 766 (1985).

134 Safford Unified Sch. Dist. v. Redding, 557 U.S. 364, 374-75 (2009).

135 Maryland v. King (King II), 133 S. Ct. 1958, 1965 (2013); United States v. Mitchell, 652 F.3d. 387, 407 (3rd Cir. 2011).

136 See Schmerber, 384 U.S. at 771 (wherein the Court referred to these factors as significant in determining the reasonableness of the intrusion involved).

137 See King II, 133 S. Ct. at 1969 (noting that buccal swab is a far more gentle process); see also Skinner, 489 U.S. at 625 (comparing breathalizer tests to blood tests).
} 
Valparaiso University Law Review, Vol. 49, N0. 3 [2015], Art. 8

does not require skin to be pierced, or a hard, foreign object to be situated inside of the body. ${ }^{138}$

This is not to say that the Court's holdings in Schmerber, Lee, and Safford control the Fourth Amendment acceptability of obtaining DNA samples from arrestees.

The Fourth Amendment intrusion in the taking of DNA samples from arrestees is not predicated on the probable cause that was present in Schmerber and Lee or the reasonable suspicion existing in Safford, but all are instructive regarding the factors that determine the extent of a physical intrusion for purposes of deciding their reasonableness under the Fourth Amendment. ${ }^{139}$

Other factors identified by the Court for assessing the overall reasonableness of a bodily intrusion are additional evidence that DNA swabbing is an acceptable practice for Fourth Amendment purposes. ${ }^{140}$ In Schmerber, the Court observed that the intrusion was reasonable in part because the test was effective at showing the amount of alcohol in the arrestee's blood.141 Similarly, the ability to identify someone by comparing samples found at a crime scene to those known to belong to a certain individual is now widely accepted by courts. ${ }^{142}$ Another factor used to assess the reasonableness of an intrusion for Fourth Amendment purposes is the uncertainty of the risk involved in obtaining evidence. ${ }^{143}$ The Court in Lee noted how this uncertainty regarding surgery to remove bullets from the body reduced the reasonableness of the intrusion. ${ }^{144}$ There is of course no such risk in the taking of DNA swabs

138 King v. Maryland (King II), 42 A.3d 549, 583 (Md. 2012) (Barbera, J., dissenting).

139 Commentators have noted the relative non-intrusive nature of swabbing the cheek for DNA samples. See, e.g., Jules Epstein, "Genetic Surveillance" - The Bogeyman Response to Familial DNA Investigations, 2009 U. ILL. J.L. TECH. \& POL'Y 141, 152 (2009) (describing buccal swabbing as "perhaps the least intrusive of all seizures"); see also Amy H. Walker, Collection of Genomic DNA by Buccal Swabs for Polymerase Chain Reaction-Based on Biomarker Assays, 107 EnVtl. Health Perspective 517, 520 (1999) (discussing benefits of buccal swab tests and steps for optimizing PCR success).

140 King II, 133 S. Ct. at 1980.

141 Schmerber, 384 U.S. at 771.

142 See King II, 133 S. Ct. at 1972 ("The DNA collected from arrestees is an irrefutable identification of the person from whom it was taken."); see also Dist. Attorney's Office v. Osborne, 557 U.S. 52, 62 (2009) (discussing DNA's power to prove innocence); Diggs v. State, 73 A.3d 306, 318 (Md. Ct. Spec. App. 2013) (exploring the ability to match DNA to a suspect with near certainty).

143 Winston v. Lee, 470 U.S. 753, 764 (1985) (elaborating on the element of uncertainty).

144 After examining in detail the risk of harm to the defendant of the bullet removal surgery in question, the Court concluded that, "the very uncertainty militates against finding the operation to be 'reasonable."' Id. at 766. 
from the cheeks of arrestees. ${ }^{145}$ Finally, when the Court approved the suspicionless drug testing in Skinner v. Railway Labor Executives Association, it noted that the procedure for obtaining the urine samples there may be performed safely outside a hospital environment. ${ }^{146}$ This is true as well for the use of buccal swabs in obtaining DNA samples from arrestees. ${ }^{147}$

\section{Uses of DNA Evidence}

In addition to the nature of the physical act involved when the government conducts a search or seizure, the extent of the overall intrusion on one's privacy is affected as well by the uses to which that evidence is put. ${ }^{148}$ In Ferguson v. City of Charleston, the Court examined the reasonableness of drug testing involving a physical intrusion similar to the type it had found reasonable in previous cases. ${ }^{149}$ The Court regarded the drug testing in Ferguson as a greater intrusion than in the previous cases because in those cases, "there was no misunderstanding about the purpose of the test or the potential use of the test results, and there were protections against the dissemination of the results to third parties." 150

Statutes that permit the DNA testing of arrestees should be limited in their uses. ${ }^{151}$ The subjects should be notified of the purposes of the test and, most importantly, the DNA should not be used for purposes that go beyond identifying the subject and comparing the sample taken from the arrestee to DNA samples found at the scenes of serious crimes. ${ }^{152}$ The Maryland statute at issue in King I limits the use of DNA samples taken from arrestees to the "identification" of the subject. 153

145 See, e.g., Walker, supra note 139, at 520 (describing buccal swabbing as a relatively noninvasive means of obtaining DNA "that pose[s] lowered risk for both the subject and laboratory personnel").

146 Skinner v. Ry. Labor Execs. Ass'n, 489 U.S. 602, 634 (1989).

$147 \quad$ King II, 133 S. Ct. at 1968.

148 Bd. of Educ. v. Earls, 536 U.S. 822, 834 (2002).

149 Ferguson v. Charleston, 532 U.S. 67, 77 (2001). The Court looked at the drug testing it had found reasonable in Skinner, 489 U.S. at 634. Compare Veronia Sch. Dist. v. Acton, 515 U.S. 646, 665 (1995), and Nat'1 Treasury Emps. Union v. Von Raab, 489 U.S. 656, 677 (1989), with Chandler v. Miller, 520 U.S. 305, 323 (1997) (illustrating circumstances where the Supreme Court had found the testing unreasonable).

150 Ferguson, 532 U.S. at 78 (emphasis added).

151 See MD. CODE ANN., Pub. SAFETY § 2-505(b)(1) (2003) (limiting the use of DNA records); id. $\S 2-505(b)(2)$ (providing restrictions on the use of DNA samples).

$152 \quad$ Id. $\S 2-505$.

153 Maryland v. King (King II), 133 S. Ct. 1958, 1967 (2013). “Only DNA records that directly relate to the identification of individuals shall be collected and stored." MD. CODE ANN., PUB. SAFETY § 2-505(b)(1). 
Valparaiso University Law Review, Vol. 49, N0. 3 [2015], Art. 8

This includes the use of the DNA sample for comparative purposes but forbids any other use.154 In fact, the statute provides for criminal sanctions for anyone improperly using the samples or disseminating them to third parties. ${ }^{155}$ Additionally, the Maryland statute prohibits the kind of testing that would reveal intimate details about the subject. ${ }^{156}$ As the judge who dissented to the Maryland Court of Appeals decision in King II noted, the statute there "effectively restricts the testing of DNA to the [thirteen] loci specified by the FBI and CODIS[,] ... [t] hese specific codi are non-coding; 'in other words, the genetic material at these locations is not known to determine a human attribute such as height, weight, or susceptibility to a particular disease.'"157 In sum, this means the loci involved in such testing, sometimes called "junk DNA," "cannot reveal any genetic information about an arrestee, other than that the arrestee is identifiably different from other members of the human race." 158

In distinguishing DNA testing from the use of fingerprints, the state court majority opinion in King II noted that broad DNA testing, unlike fingerprints, could reveal intimate details about an individual, what is referred to as a "genetic treasure map." 159 This is certainly true, however, given the restrictions in the Maryland statute and the impossibility of revealing such details except by violating the law-it seems the Maryland court was overly concerned with possible future misuse of the samples. ${ }^{160}$ As the U.S. Court of Appeals for the Ninth Circuit wrote in United States v. Pool:

But beyond the fact that the DNA Act itself provides protections against such misuse, our job is limited to resolving the constitutionality of the program before us, as it is designed and as it has been implemented. In our

\footnotetext{
154 MD. CODE ANN., Pub. SAfETY §§ 2-505(a)(2) \& (b)(2).

"A person who violates subsection (a), (b), or (c) of this section is guilty of a misdemeanor and on conviction is subject to imprisonment not exceeding [five] years or a fine not exceeding [\$5000] or both." Id. § 2-512(e). "A person who violates subsection (d) of this section is guilty of a misdemeanor and on conviction is subject to imprisonment not exceeding [one] year or a fine not exceeding [\$1000]." Id. § 2-512(f).

156 "All personal identifiers shall be removed before information is entered into the population data base." Id. § 2-509(b).

157 King v. Maryland (King I), 42 A.3d 549, 584 (Md. 2012).

158 Id. at 585; see H.R. REP. No. 106-900, pt. 1, at 27 (2000) (“[G]enetic markers used for forensic DNA testing were purposely selected because they are not associated with any known physical or medical characteristics."); see also CODIS and NDIS Fact Sheet, supra note 52 (discussing the type of information stored in CODIS DNA databases).

159 King I, 42 A.3d at 577; United States v. Pool, 621 F.3d 1213, 1238 (9th Cir. 2010).

160 See King I, 42 A.3d at 578 (finding DNA to encompass a heightened security threat).
} 
system of government, courts base decisions not on dramatic Hollywood fantasies,... but on concretely particularized facts developed in the cauldron of the adversary process and reduced to an assessable record. If, ... and when, some future program permits the parade of horribles the DNA Act's opponents fearunregulated disclosure of CODIS profiles to private parties, genetic discrimination, state-sponsored eugenics ....-we have every confidence that courts will respond appropriately. ${ }^{161}$

The possibility of overreaching can never be eliminated, but it is unreasonable to negate an otherwise acceptable government activity when both science and law substantially limit that possibility. ${ }^{162}$

Courts have universally permitted DNA testing of convicted criminals where this same slim possibility of misuse exists. ${ }^{163}$ Even accepting the proposition that the expectation of privacy for one convicted of a crime is less than one arrested, but still presumed to be innocent, it is difficult to see why this difference would allow DNA testing of convicts if there was a serious risk that such testing could reveal the "genetic treasure map" alluded to above.164 It is crucial therefore to limit the use of the DNA samples taken from arrestees in a manner similar to the way this is accomplished under the Maryland statute. 165 This includes a limit on the kind of genetic material tested and severe penalties for anyone who reveals any information from the testing that is not authorized by the statute. ${ }^{166}$

\section{Non-arbitrariness}

The Supreme Court long ago established the principle that for intrusions into areas protected by the Fourth Amendment that take place without individualized suspicion, the reasonableness of such intrusions depends to a significant degree on the amount of discretion that individual government officials have in executing the searches or

\footnotetext{
Pool, 621 F.3d at 1221-22 (quoting United States v. Kincade, 379 F.3d 813, 837-38 (9th Cir. 2004)). 
Valparaiso University Law Review, Vol. 49, N0. 3 [2015], Art. 8

seizures in question. 167 The more discretion a search or seizure involves, the more intrusive it is, and this enhanced intrusiveness weighs against the reasonableness of the procedure for Fourth Amendment purposes. ${ }^{168}$ Although the objective physical intrusion of two procedures may be similar, the fact that one allows the police greater discretion regarding whom to search increases the anxiety of the individual and therefore the subjective degree of the intrusion. ${ }^{169}$

Searches or seizures conducted without individualized suspicion at the discretion of officers in the field can be arbitrary or discriminatory, and a search that is either of these would conflict with Fourth Amendment principles. ${ }^{170}$ In contrast, the regularity of a government search or seizure avoids the kind of randomness and arbitrariness against which the Fourth Amendment is designed to protect. ${ }^{171}$ For example, in assessing the constitutionality of border area automobile seizures designed to detect smugglers of undocumented aliens that were conducted without individualized suspicion, the Court allowed them when done at a checkpoint stopping all cars but not when done by officers in the field making individual decisions about which cars to stop. ${ }^{172}$ In permitting the inspection of automobile parts dealerships without individualized suspicion, one of the criteria used by the Court in determining the reasonableness of such inspections was the systematized

167 See Marshall v. Barlow's, Inc., 436 U.S. 307, 323 (1978) (“warrantless searches devolves almost unbridled discretion upon executive and administrative officers"); see also United States v. Biswell, 406 U.S. 311, 316 (1972) (demonstrating that warrantless searches must be reasonable under the Fourth Amendment); Colonnade Catering Corp. v. United States, 397 U.S. 72, 74 (1970) (conveying that warrantless searches are permitted under certain circumstances).

168 Marshall, 436 U.S. at 312.

169 United States v. Martinez-Fuerte, 428 U.S. 543, 557-58 (1976).

170 United States v. Brignoni-Ponce, 422 U.S. 873, 883 (1975); see Delaware v. Prouse, 440 U.S. 648, 653-54 (1979) (affirming the importance of imposing limitations on government officials).

171 Marshall, 436 U.S. at 314.

172 Martinez-Fuerte, 428 U.S. at 559; Almeida-Sanchez v. United States, 413 U.S. 266, 273 (1973); Prouse, 440 U.S. at 653-54. The Supreme Court prohibited the suspicionless stops of individual cars to check for drivers licenses and registration, and the Court stated, "[t]he essential purpose of the proscriptions in the Fourth Amendment is to impose a standard of 'reasonableness' upon the exercise of discretion by government officials, including law enforcement agents, in order 'to safeguard the privacy and security of individuals against arbitrary invasions.'" Id.; see Brignoni-Ponce, 422 U.S. at 882 (limiting police discretion in patrol stops). Similarly, when it approved the use of sobriety checkpoints to apprehend and deter intoxicated drivers, the Court noted the reduced level of the subjective intrusion resulting from the fact that in stopping all the cars that approached the checkpoints, the police exercised no discretion. Michigan Dept. of State Police v. Sitz, 496 U.S. 444, 452-53 (1990). 
nature of the inspection scheme and how it largely removed discretion from those conducting the inspections. ${ }^{173}$

Particularly noteworthy regarding the significance of discretion in searches or seizures of individuals performed without individualized suspicion is the dissenting opinion of Justice Stevens in Samson $v$. California and the manner in which the majority opinion responded to it. ${ }^{174}$ Justice Stevens criticized the decision in Samson, which allowed police unlimited discretion to search parolees without any individualized suspicion of criminal wrongdoing. ${ }^{175}$ He asserted that previous Supreme Court decisions have dispensed with individualized suspicion in special needs cases where "programmatic safeguards [are] designed to ensure evenhandedness in application," and that "if individualized suspicion is to be jettisoned, it must be replaced with measures to protect against the state actor's unfettered discretion." 176 Justice Stevens argued that the California statute at issue contained no such limiting policies "to rein in officers and furnish a bulwark against the arbitrary exercise of discretion that is the height of unreasonableness." 177 The response to Justice Stevens' argument from the majority disputed his claim that the statute allowed for unbridled discretion because of California case law and statutory prohibitions that generally disallow arbitrary and capricious searches. ${ }^{178}$ Dubious as the majority's response here might be, it is noteworthy that the Court did not dispute Stevens' assertion that were these intrusions too discretionary, they would be unreasonable. ${ }^{179}$

Regardless of whether one accepts Samson's majority view that discretion was effectively limited in a search, notwithstanding the fact that virtually any parolees could be searched and seized without

\footnotetext{
173 The Supreme Court wrote:

The statute's inspection program in terms of the certainty and regularity of its application, [must] provid[e] a constitutionally adequate substitute for a warrant. In other words, the regulatory statute must perform the two basic function of a warrant: it must advise the owner of the commercial premises that the search is being made pursuant to the law and has a properly defined scope, and it must limit the discretion of the inspecting officers.

New York v. Burger, 482 U.S. 691, 703 (1987).

174 Samson v. California, 547 U.S. 843, 859 (2006) (Stevens, J., dissenting).

175 Id.

176 Id. at 860

177 Id. at $860-61$.

178 Id. at 856

179 "The concern that California's suspicionless search system gives officers unbridled discretion to conduct searches, thereby inflicting dignitary harms that arouse strong resentment in parolees and undermine their ability to reintegrate into productive society, is belied by California's prohibition on 'arbitrary, capricious or harassing' searches." Id.
} 
individualized suspicion under California's enabling statute, the contrast with DNA testing of arrestees under an appropriately limiting law, such as that in Maryland, is stark. ${ }^{180}$ The Maryland statute requires that everyone arrested for certain crimes and in police custody must have a DNA sample obtained in the same manner and put to the same uses as all others in the same group. ${ }^{181}$ Virtually no discretion or arbitrariness is permitted regarding the nature of the intrusion here, and thus on this issue, the search and seizure under the Maryland DNA statute is far less intrusive than the search approved by the Court in Samson. ${ }^{182}$ It is hardly surprising then that the King II Court found that the relatively discretionfree nature of the Maryland DNA testing procedure weighed heavily in determining its reasonableness under the Fourth Amendment. ${ }^{183}$

The extent of the intrusion is one of two integral parts of the balancing test used to determine the reasonableness under the Fourth Amendment of personal searches and seizures conducted without individualized suspicion. ${ }^{184}$ The obtaining and use of DNA samples taken from arrestees detained in custodial facilities, when authorized under protective statutes such as the one at issue in King II, is a relatively minor intrusion under the standards applied by the Supreme Court. ${ }^{185}$ The process of the sample taking involves a safe, brief, non-harmful, and minimally intrusive physical act. ${ }^{186}$ The taking is conducted in a standardized non-arbitrary manner and is risk-free. ${ }^{187}$ Finally, when strong protections against improper use and dissemination of the results of the testing are included within the authorizing statute, the extent of the intrusion is even more minimal. ${ }^{188}$

\section{B. Nature of Government Interest}

The next step in the balancing process then is to assess the extent of the government interest in taking and testing DNA samples of

\footnotetext{
180 Maryland v. King (King I), 133 S. Ct. 1958, 1970 (2013). See generally Samson, 547 U.S. at 856 (providing the Court's holding). 
arrestees. ${ }^{189}$ DNA evidence when obtained and tested through accepted means is very reliable. ${ }^{190}$ It can establish to a near mathematical certainty that someone was present at a certain location or at some point possessed a certain object. ${ }^{191}$ Crime solving techniques of far less reliability are used by police in solving crimes and permitted by courts in adjudicating them. ${ }^{192}$ Evidence, both empirical and anecdotal, attests to the importance of DNA evidence in helping to convict those guilty of serious crimes and exonerate those who are innocent. ${ }^{193}$ No more important purpose exists for the use of evidence or for that matter for our system of criminal justice.

DNA evidence has been used to help apprehend those guilty of recent crimes and to solve cold cases, often thought to be insolvable. ${ }^{194}$ DNA samples were often times not available from the scenes of past serious crimes. ${ }^{195}$ Now it is standard procedure in many police departments to seek DNA samples from the scenes of serious crimes just as looking for fingerprints or other physical evidence is part of crime

189 See id. at 1962 (discussing government interest)

190 See Julie E. Samuels et al., Collecting DNA at Arrest: Policies, Practices, and Implications, URBAN INST. (May 2013), available at http://www.urban.org/uploadedpdf/412831Collecting-DNA-at-Arrest-Policies-Practices-and-Implications-Report.pdf, archived at http://perma.cc/BJ2V-2DHH (providing a background of DNA collections and policies regarding arrests).

191 Id.

192 See Jennifer L. Mnookin, Fingerprint Evidence in an Age of DNA Profiling, 67 BROOK. L. REV. 13, 63 (2001) (comparing fingerprint evidence to DNA evidence).

193 See DNA Exonerations Nationwide, INNOCENCE PROJECT (Nov. 7, 2014), available at http://www.innocenceproject.org/Content/DNA_Exonerations_Nationwide.php, archived at http://perma.cc/GU76-CNE2 (discussing DNA exonerations for people wrongfully convicted of crimes); CODIS and NDIS Fact Sheet, supra note 52 (discussing the CODIS and NDIS facts). In assessing the manner in which criminal investigations are aided by the use of DNA comparisons, the FBI reports that the National DNA Index ("NDIS") contains over $11,015,147$ offender profiles, 1,922,415 arrestee profiles, and 565,159 forensic profiles as of June 2014. Id. Ultimately, the success of the CODIS program will be measured by the crimes it helps to solve. Id. CODIS's primary metric, the "Investigation Aided," tracks the number of criminal investigations where CODIS has added value to the investigative process. Id. As of June 2014, CODIS has produced over 250,809 hits assisting in more than 239,317 investigations. Id.

194 See infra note 204 and accompanying text (discussing how DNA evidence has helped exonerate wrongfully convicted individuals).

195 See Non-DNA Exonerations, INNOCENCE PROJECT (Nov. 7, 2014), available at http://www.innocenceproject.org/know/non-dna-exonerations.php, archived at http:/ / perma.cc/L564-V8P8 (discussing how individuals have been exonerated by other means besides DNA evidence). 
Valparaiso University Law Review, Vol. 49, N0. 3 [2015], Art. 8

686

scene investigation. ${ }^{196}$ We can, therefore, expect that many more crimes than in the past may be solved through the use of DNA evidence. ${ }^{197}$

Collecting DNA from arrestees expands the number of people whose samples can be compared to those found at crime scenes and should increase the number of crimes solved through DNA hits. ${ }^{198}$ If the extent of intrusion to the individual arrested for a serious felony is minor, as discussed above, this important government interest satisfies the test for reasonableness under the Fourth Amendment and should be permitted. ${ }^{199}$

There are many accounts of DNA evidence being used to link people to awful crimes.200 For example, DNA testing was used to identify and eventually convict the infamous "Green River Killer" who raped and murdered dozens of women in the Seattle-Tacoma area in the 1980s and 1990s. ${ }^{201}$ In 2001, forensic investigators decided to re-examine evidence compiled years before with two new modes of DNA analysis and found that a sample of semen left on a victim matched Gary Ridgway's DNA. ${ }^{202}$ Confronted with the weight of this evidence, Ridgeway pled guilty and was sentenced to forty-eight consecutive life sentences with no possibility of parole. ${ }^{203}$

196 See Samuels, supra note 190 (discussing the DNA collection practice at arrests).

197 See Jay Siegel \& Susan D. Narveson, Why Arrestee DNA Legislation Can Save Indiana Taxpayers over \$60 Million Per Year (Jan. 2009), available at http://dnasaves.org/files/ IN_DNA_Cost_Savings_Study.pdf, archived at http://perma.cc/5VPM-KSCQ (discussing an anticipated increase in solved crimes).

198 Id

199 See supra Part V.A (discussing the extent of intrusion of DNA testing).

200 See Advancing Justice Through DNA Technology: Using DNA to Solve Crimes, U.S. DEP'T JUSTICE (Nov. 7, 2014), available at http://www.justice.gov/ag/advancing-justice-throughdna-technology-using-dna-solve-crimes, archived at http://perma.cc/MG7M-EQE9 ("In 1999, New York authorities linked a man through DNA evidence to at least [twenty-two] sexual assaults and robberies that had terrorized the city. In 2002, authorities in Philadelphia, Pennsylvania, and Fort Collins, Colorado, used DNA evidence to link and solve a series of crimes (rapes and a murder) perpetrated by the same individual."); P. Solomon Banda, Police Use DNA to Solve Property Crimes, NBC News (Oct. 20, 2008), available at http://www.nbcnews.com/id/27284393/ns/technology_and_science-science /t/police-use-dna-solve-property-crimes/\#.U9pyAo1dU7p, archived at http://perma.cc/ Y2YG-8UN4 ("RazJohn Smyer, a suspect in a string of Denver-area break-ins, often checked his victims' refrigerators and helped himself to a drink. The soda cans he left behind gave police enough DNA evidence to link him to five burglaries. He's now serving a [twenty]-year sentence.").

201 See Elizabeth Svoboda, Cold Case is Closed by DNA Match: Green River Killer, N.Y. TIMES (May 11, 2009), available at http://www.nytimes.com/2009/05/12/science/12filedna.html?_\&_r=0, archived at http://perma.cc/5MSZ-ULV5 (discussing the "Green River" killer's capture).

202 Id.

203 Id. 
Of additional significance are those cases in which DNA evidence not only links individuals to crimes but where it also exonerates those who have been charged or convicted of those crimes. ${ }^{204}$ For nearly thirty years, Erie County, New York, was terrorized by a man who came to be known as the "Bike Path Rapist." 205 Anthony Capozzi, the man who was believed to be responsible for the rapes and murder of three women committed by the Bike Path Rapist, was convicted in 1984 of two of the rapes based on eyewitness identification and sentenced to twenty-five years in prison. 206 However, while Capozzi was in prison, additional rapes and murders took place. ${ }^{207}$ Those murders were incredibly similar to prior rapes and murders, including the two for which Capozzi was incarcerated. ${ }^{208}$ The final murder took place on a local bike path in 2006 and a task force was formed to investigate the crime.209 Ultimately, Altemio Sanchez's DNA was collected from a water glass in a restaurant and found to match the DNA profile from a drop of sweat found in the last victim's car. ${ }^{210}$ While all the evidence from Capozzi's trial had been destroyed after his appeal was denied, forensic DNA tests of the clinical slides still maintained at the hospital of the two victims for which Capozzi had been convicted matched the DNA profile of Altemio Sanchez.211 Using DNA, prosecutors linked Sanchez to at least eight other attacks, including the two for which Capozzi was convicted.212 In 2007, after serving twenty-two years in prison, Capozzi was exonerated and Sanchez pled guilty to the murder of three women. ${ }^{213}$

In addition to the Capozzi case, the Innocence Project lists 321 cases where DNA evidence was instrumental in showing wrongful convictions. ${ }^{214}$ Twenty of those cases involved people who were on death row. ${ }^{215}$ In Maryland, the state from where the King II case

\footnotetext{
204 See DNA Exonerations Nationwide, supra note 204 (demonstrating the amount of individuals exonerated by DNA evidence).

205 Carolyn Thompson, Buffalo's Bike Path Rapist Sentenced, WASH. POST (Aug. 15, 2007, 12:11 AM), available at http://www.washingtonpost.com/wp-dyn/content/article/2007/ 08/14/ AR2007081400904.html, archived at http:/ / perma.cc/ A3HB-2ST8.

206 DNA Case Highlights, N.Y. STATE DIV. CRIM. Justice SERvs., http://www.criminaljustice.ny.gov/forensic/dnacasehighlights.htm (last visited Mar. 20, 2015), archived at http:/ / perma.cc/39B-L8J5.

207 Id.

$208 \quad I d$.

209 Id.

$210 \quad I d$.

$211 \quad I d$

212 Thompson, supra note 205.

$213 \quad I d$.

214 DNA Exonerations Nationwide, supra note 204.

215 Id.
} 
Valparaiso University Law Review, Vol. 49, No. 3 [2015], Art. 8

emanates, the most famous case is that of Kirk Bloodsworth. ${ }^{216}$ Bloodsworth was convicted of the rape and murder of a nine-year-old girl in a brutal 1984 crime. $^{217}$ He was convicted based on an identosketch, which looked like him, and the testimony of five eyewitnesses claiming to have seen Bloodsworth with the victim.218 It was the discovery and comparison of DNA found on the clothing of the victim that ultimately exonerated Bloodsworth and pointed to the man who had actually raped and murdered Dawn Hamilton. ${ }^{219}$ Until DNA evidence freed him, Kirk Bloodsworth served more than eight years in prison, two on death row, for a crime he did not commit. ${ }^{220}$

One of the most notorious wrongful convictions occurred in what became known as the Central Park Jogger Case.221 Based in part on the confessions of some of them, five men were convicted of raping a woman as she jogged through New York's Central Park.222 Only after some of the men served more than a decade in prison did another man confess to the crime. ${ }^{223}$ It was, however, the fact that his DNA matched that of the semen found in the victim that made absolutely clear that those serving time for the crime had to be released. ${ }^{224}$ DNA evidence is crucial in such a case because many are unwilling to exculpate someone convicted of a crime based on the word of another criminal. ${ }^{225}$ Nothing

216 See Kirk Bloodsworth, INNOCENCE PROJECT, http://www.innocenceproject.org/casesfalse-imprisonment/kirk-bloodsworth (last visited Apr. 16, 2015), archived at http://perma.cc/Q7BD-W5H2 (providing information regarding Kirk Bloodsworth and his 1985 conviction).

217 Id.

$218 \quad I d$.

219 See id. (establishing Bloodsworth's innocence and exoneration based on DNA).

220 Id.

221 See, e.g., Susan Saulny, Convictions and Charges Voided in the '89 Central Park Jogger Attack, N.Y. TIMES (Dec. 20, 2002), available at http://www.nytimes.com/2002/12/20/ nyregion/convictions-and-charges-voided-in-89-central-park-jogger-attack.html, archived at http:/ / perma.cc/L8KU-U3QX (attributing the exoneration of five young men in a savage beating to DNA evidence).

222 Id.

223 See id. (explaining that another man, Matias Reyes, confessed to raping the New York woman).

224 See Robert D. McFadden, Boys' Guilt Likely in Rape of Jogger, Police Panel Says, N.Y. TIMES (Jan. 28, 2003), available at http://condemnationofblackness.voices.wooster.edu/ files/2013/10/BOYS-GUILT-LIKELY-IN-RAPE-OF-JOGGER-POLICE-PANEL-SAYS-NewYork-Times.pdf, archived at http://perma.cc/8HFL-5RV4 (establishing DNA as the reason the convicted man had to be released). Michael Armstrong, one of the authors of a NYC Police Department report on the case, said "the panel did not dispute the legal necessity of setting aside the convictions of the five defendants based on the new DNA evidence that Mr. Reyes had raped the jogger." Id.

225 Id. (quoting Armstrong, "we think the word of a serial rapist killer is not something to be heavily relied upon"). 
contaminates the criminal justice system more than when innocent people are convicted of crimes.226 The ability of DNA evidence to exonerate such people has been demonstrated and is an integral component of the government's interest in expanding their DNA sample list with the specimens of those arrested and incarcerated for serious crimes.227 The Capozzi, Bloodsworth and Central Park Jogger cases show how identification testimony and confessions, two types of evidence that lead to lots of convictions, can be incorrect and that such mistakes can result in tragic consequences. ${ }^{228}$ It is hard to imagine the injustices that would result in these cases had they not been corrected with DNA evidence. ${ }^{229}$

For the government interest to be substantial regarding the taking of DNA samples from those arrested for serious crimes, there must be a specific benefit derived from obtaining the samples upon arrest and not depending on a conviction before doing so. ${ }^{230}$ Studies indicate that such a benefit is in fact present. 231 This benefit accrues both through apprehending the actual perpetrators of past violent crimes and, in doing so, preventing future crimes by imprisoning the individuals before they can re-offend.232 For example, a Virginia study found that between

226 See Berger v. United States, 295 U.S. 78, 88 (1935) (stating the goal of the criminal justice system is to see "that guilt shall not escape nor innocence suffer"). What is famously known as Blackstone's formulation makes the same point differently, "[i]t is better that ten guilty persons escape, than that one innocent suffer." Words of Justice, HARV. L. SCH. LIBR., http://library.law.harvard.edu/justicequotes/explore-the-room/south-4/ (last visited Mar. 20, 2015), archived at http:// perma.cc/4RXE-Z4QL.

227 DNA Exonerations Nationwide, supra note 204.

228 See Bloodsworth, supra note 216 (illustrating that Bloodsworth spent years on death row for a crime he did not commit).

229 See DNA Exonerations Nationwide, supra note 204 (conveying the success of DNA in exonerating those wrongfully convicted).

230 See infra Part VII (elaborating on the primary purpose test).

231 Arrestees, DNA FORENSICS, http://www.dnaforensics.com/Arrestees.aspx (last visited Mar. 20, 2015), archived at http://perma.cc/SD5D-YXY7; Collecting DNA at Arrest, supra note 190; DENVER'S STUdy ON PREVENTABLE CRIMES, DENV. DisT. ATT'Ys OfF., available at http://www.denverda.org/DNA_Documents/Arrestee_Database/Denver\%20Preventable \%20Crime\%20Study1.pdf (last visited Apr. 16, 2015), archived at http://perma.cc/4Z4689NG; Maryland Study on Preventable Crimes, MD. CRIM. JUSTICE INFO. SYS., available at http://www.dnaresource.com/documents/MarylandDNAarresteestudy.pdf (last visited Mar. 20, 2015), archived at http:/ / perma.cc/4GTL-N5NM.

232 In its assessment of DNA testing of arrestees, the Urban Institute reported that: Research demonstrates that a considerable number of individuals will commit multiple crimes, suggesting that collecting DNA from repeat offenders could assist law enforcement in solving crimes. Proponents of arrestee DNA laws recognize that certain individuals who are arrested but not convicted for a qualifying offense have committed crimes (or will commit future crimes) for which there might be forensic evidence. Even those who are ultimately convicted may remain in the 
Valparaiso University Law Review, Vol. 49, No. 3 [2015], Art. 8

2003 and 2009, the DNA testing of arrestees resulted in 559 "hits," eighty-nine of which were associated with sexual offense cases.233 A Maryland study of just three offenders concluded that had their DNA been obtained upon their arrest for a serious crime, twenty crimes could have been prevented. ${ }^{234}$ The DNA sampling of arrestees obtained under the Maryland law at issue in King II from 2009 through 2013 resulted in 303 "hits," ninety-three arrests, and sixty-one convictions. ${ }^{235}$ A study done by the District Attorney's Office in Denver concluded that had the DNA of just five people arrested for felonies been taken upon their arrest, forty-seven violent crimes, including three murders and eighteen sexual assaults, could have been prevented. ${ }^{236}$

There are many reasons why arrests do not lead to convictions, some related to whether the individual actually committed the crime for which he has been arrested and many that do not.237 If the use of DNA comparisons were limited to only those convicted of crimes, a critically important investigative tool might be delayed or lost entirely. ${ }^{238}$ For those who have not been convicted after arrest, statutes, such as the Maryland one at issue in the King II case, appropriately require

community between their arrest and conviction, which could provide an opportunity for additional criminal offending before DNA can be collected, analyzed, and used to establish guilt. The expansion of offender databases to include arrestees seeks to remedy this gap by identifying new suspects in a criminal investigation and resolving cases faster. Proponents of arrestee DNA frequently cite averted crime as a short- and long-term outcome. Based on findings from their costbenefit analysis of proposed arrestee DNA legislation in Indiana, Siegel and Narveson (2009) concluded, "with an arrestee law in place, the first time [a criminal] is arrested he will be linked to his long record of anonymous violent crimes, and can be removed from the population and the opportunity to do further harm-saving the government's cost to investigate, prosecute, and adjudicate those prevented crimes." In their retrospective case studies exploring the criminal trajectories of known criminals, several jurisdictions have arrived at the same conclusion as Siegel and Narveson, arguing that if DNA had been collected earlier in the individuals' criminal careers, crimes may have been prevented.

Collecting DNA at Arrest, supra note 190, at 7.

233 Arrestees, supra note 231.

234 Maryland Study on Preventable Crimes, supra note 231.

235 See Arrestees, supra note 231 (showing the total number of "hits", arrests, and convictions between 2009 and 2013 for charged offenders).

236 DENVER'S STUDY ON PREVENTABLE CRIMES, supra note 231.

237 See Collecting DNA at Arrest, supra note 190, at iii (discussing how many arrests do not lead to convictions).

238 See supra note 204 (addressing the results of several studies, which indicate the significance of a DNA database in exonerations). 
expungement of those samples.239 Therefore, with regard to those who have been arrested for serious crimes but not subsequently convicted, their DNA is on file only for the time between arrest and disposition of their case. ${ }^{240}$ Assuming again that the sample is used only to identify the arrestee and to see if he has been involved in other serious crimes, the intrusion to his privacy rights would seem minimal compared to the government's need to successfully investigate and solve those crimes, particularly if others have been wrongfully charged with or convicted of those crimes. ${ }^{241}$ This is especially true when considering how the success of criminal investigations can be compromised by delays in obtaining crucial evidence. ${ }^{242}$

\section{DiMINISHED EXPECTATION OF PRIVACY}

The previous section of this Article analyzed the extent of the intrusion involved when the government obtains a DNA sample from a buccal swab taken from an arrestee in a custodial institution. ${ }^{243}$ This intrusion also includes the uses to which a sample is put, specifically to confirm the identity of the subject and to link the subject to serious crimes. ${ }^{244}$ In assessing the degree to which such an intrusion factors into the ultimate determination of reasonableness under the Fourth Amendment, courts must also take into consideration whether the subject of the intrusion has a diminished expectation of privacy. ${ }^{245}$ Such a diminished expectation allows for government searches and seizures that might not otherwise be considered reasonable under the Fourth

239 See MD. PUB. SAFETY § 2-504 (2011) (explaining that DNA samples may be destroyed if the individual is not convicted after arrest).

240 See Collecting DNA at Arrest, supra note 190, at 1 (stating that DNA specimens are collected from an individual following an arrest but before case disposition).

241 See DNA Exonerations Nationwide, supra note 204 (illustrating exonerations of those wrongfully convicted).

242 See Nathan James, DNA Testing in Criminal Justice: Background, Current Law, Grants, and Issues, CONG. RES. SERV. 1, 8 (Dec. 6, 2012), available at http://fas.org/sgp/ $\mathrm{crs} / \mathrm{misc} / \mathrm{R} 41800 . \mathrm{pdf}$, archived at http://perma.cc/AJT7-FAS2 (discussing the problems with delays in DNA processing).

243 See supra Part V (discussing in depth the reasonableness test).

244 See supra note 2 (discussing various federal and state crimes that require the collection of a DNA sample).

245 See Maryland v. King (King II), 133 S. Ct. 1958, 1978 (2013) (explaining that the reasonableness of any search must be considered in the context of that individual's legitimate expectations of privacy); see also Vernonia Sch. Dist. 47J v. Acton, 515 U.S. 646, 654 (1995) (expressing that the nature of privacy interest is the first factor to be considered when discussing Fourth Amendment protections); O'Connor v. Ortega, 480 U.S. 709, 715 (1987) (stating that an expectation of privacy infringed upon must be reasonable to implicate the Fourth Amendment). 
Valparaiso University Law Review, Vol. 49, N0. 3 [2015], Art. 8

Amendment. ${ }^{246}$ Specifically, if a person or business has a diminished expectation of privacy, this plays a central role in permitting the government to intrude upon areas and interests protected by the Fourth Amendment without the usual requirements of individualized suspicion and a warrant. ${ }^{247}$ It is incumbent then to examine whether, and to what extent, arrestees confined to a total custodial facility have a diminished expectation of privacy. This would then factor significantly into the determination of whether DNA samples can be taken from them without suspicion and used to determine if they were involved with any other crime.

The Supreme Court has on numerous occasions held that a person or business with a diminished expectation of privacy is subject to certain types of searches and seizures that would not be permitted absent this diminished expectation. ${ }^{248}$ With businesses, this diminished expectation comes from the fact that certain facilities, such as coal mines and firearm dealerships, are pervasively regulated by the government. ${ }^{249}$

246 See Marshall v. Barlow's, Inc., 436 U.S. 307, 313 (1978) (illustrating that search warrant exceptions exist for businesses with a rich history of government oversight); see also United States v. Biswell, 406 U.S. 311, 316 (1972) (holding that warrantless inspections of firearm businesses do not violate the Fourth Amendment); Colonnade Catering Corp v. United States, 397 U.S. 72, 77 (1970) (acknowledging that reasonableness is viewed differently under the Fourth Amendment for areas where the government has broad inspection powers).

247 See New York v. Burger, 482 U.S. 691, 702 (1987) (explaining that a warrant and probable cause requirements typically required to satisfy the Fourth Amendment standards of reasonableness have a lessened application when there is a diminished expectation of privacy); see also New Jersey v. T.L.O., 469 U.S. 325, 353 (1985) (Blackmun, J., concurring) (describing the importance of being able to conduct searches immediately in certain situations, such as teaching in a public school, and that requiring evidence for probable cause would not allow that immediate search); Biswell, 406 U.S. at 315 (contrasting the government interest in regulating the liquor industry and the firearm industry to assess the expectation of privacy for licensed dealers); Colonnade Catering Corp., 397 U.S. at 75-77 (providing background on government regulation on the liquor industry and explaining that the history of heavy government oversight causes a diminished expectation of privacy and allows for warrantless inspections).

248 See Biswell, 406 U.S. at 316 (justifying unannounced, warrantless inspections by distinguishing business industries with diminished expectations of privacy); see also Burger, 482 U.S. at 702 (discussing the significance of "closely regulated" industries that create a diminished expectation of privacy and serve as exceptions to the traditional warrant and probable cause requirements); Marshall, 436 U.S. at 320 (revealing that entitlement to inspection without prior notice can be based on reasonable legislature and administrative standards for certain businesses).

249 See Burger, 482 U.S. at 701 (reasoning that business owners in "closely regulated" industries have a diminished privacy expectation because the industries are pervasively regulated by the government, and owners have knowledge that their business records and other operating conditions may be inspected and heavily regulated); see also Biswell, 406 U.S. at 316 (demonstrating that an arms dealer knows his business records will be subject to inspection when he decides to engage in the pervasively regulated field); Colonnade 
Accordingly, the owners of such businesses are on notice that their premises are subject to government inspections without probable cause or specific warrants. ${ }^{250}$ Regarding searches and seizures of individuals, the Supreme Court has held that certain jobs or the overall status of some people can result in their having a reduced privacy expectation compared to the public at large.251 Probationers, parolees, certain high school students, railroad workers involved in accidents, and federal employees about to be transferred to positions where they will be carrying firearms are among those that have been deemed to possess such a diminished expectation of privacy. ${ }^{252}$

Some of the Supreme Court's decisions regarding which groups have a diminished expectation of privacy are highly questionable. ${ }^{253}$ For example, in justifying various types of searches of automobiles and containers within automobiles, the Court relied on what it regarded as the diminished expectation of privacy that one has in an automobile. ${ }^{254}$ This diminished expectation was said to be due in part to the fact that regulations exist regarding the ownership, use, and maintenance of

Catering Corp., 397 U.S. at 77 (assessing the pervasiveness of regulations on the liquor industry and holding that warrantless searches are permissible under the Fourth Amendment).

250 See, e.g. Burger, 482 U.S. at 701 (stating that firearms dealers, and other business owners, that choose to engage in the heavily regulated business, have knowledge that their business records, firearms, and ammunition will be subject to inspection).

251 See United States v. Knights, 534 U.S. 112, 120 (2001) (asserting that probationers have a diminished expectation of privacy); Samson v. California, 547 U.S. 843, 850 (2006) (comparing the privacy of a parolee to a probationer and holding that parolees have fewer expectations of privacy); Bd. of Educ. of Indep. Sch. Dist. No. 92 of Pottawatomie Cnty. v. Earls, 536 U.S. 822, 830-32 (2002) (finding that a student's privacy interest is limited in a public school environment); New Jersey v. T.L.O., 469 U.S. 325, 338-39 (1985) (holding that students still have some privacy interests and those interests are not waived completely by simply carrying bags onto school grounds); Skinner v. Ry. Labor Execs. Ass'n, 489 U.S. 602, 628 (1989) (acknowledging that railroad workers have a diminished expectation of privacy as it relates to toxicology testing after work accidents because of the dangerousness associated with their occupation); Nat'1 Treasury Emps. Union v. Von Raab, 489 U.S. 656, 672 (1989) (reasoning that federal employees required to carry firearms or work in the interdiction of illegal drugs have a diminished expectation of privacy).

252 See infra notes 248-51 and accompanying text (discussing employees with a diminished expectation of privacy).

253 See infra notes 254-56 and accompanying text (illustrating that those in automobiles have a diminished expectation of privacy).

254 See Cardwell v. Lewis, 417 U.S. 583, 590 (1974) (reasoning that the amount of privacy expected in an automobile is diminished). In Chambers $v$. Maroney, the Supreme Court chronicled the development of car searches and seizures. 399 U.S. 42, 49 (1970). The original justification for warrantless searches of vehicles based on probable cause was due to the mobility of the automobile. Carroll v. United States, 267 U.S. 132, 151 (1925). 
Valparaiso University Law Review, Vol. 49, N0. 3 [2015], Art. 8

automobiles. ${ }^{255}$ Still it is difficult to see, as the Court has held, how requiring the registration of automobiles and mandating certain types of periodic vehicle inspections results in an individual having less of an expectation of privacy in a paper bag locked in the trunk of her car than when that same bag is being openly carried in the street. ${ }^{256}$ In sanctioning the suspicionless drug testing of certain high school students, the Court found a reduced expectation of privacy in the fact that these students participated in extracurricular activities. ${ }^{257}$ Leaving aside the fact that most high school students participate in one or more such activities, it is difficult to understand why a fourteen-year-old student who joins the chess club or debate society deserves less privacy than other students. ${ }^{258}$ Additionally, it is even harder to imagine that students participating in extracurricular activities are, or should be

255 See Cady v. Dombrowski, 413 U.S. 433, 441-42 (1973) (relying on the fact that there are many existing state and federal laws that govern the ownership and operation of automobiles to rationalize the diminished expectation of privacy). In explaining those regulations, the Court in Cady wrote, "[a]ll states require vehicles to be registered and operators to be licensed. States and localities have enacted extensive and detailed codes regulating the condition and manner in which motor vehicles may be operated on public streets and highways." Id. at 441. Automobiles periodically undergo official inspection, and they are often taken into police custody in the interests of public safety. South Dakota v. Opperman, 428 U.S. 364, 368 (1976).

256 This difficulty was the result of the Court's holding in California v. Acevedo, 500 U.S. 565, 580-81 (1991), and led to Justice Stevens' comment in his dissent that:

For surely it is anomalous to prohibit a search of a briefcase while the owner is carrying it exposed on a public street yet to permit a search once the owner has placed the briefcase in the locked trunk of his car. One's privacy interest in one's luggage can certainly not be diminished by one's removing it from a public thoroughfare and placing it-out of sight-in a privately owned vehicle.

Id. at 598 (Stevens, J., dissenting); see also CHARLES H. WHITEBREAD \& CHRISTOPHER Slobogin, CRIMINAl Procedure: An ANAlysis of CASES AND CONCEPTS 195-96 (4th ed. 2000). The authors state:

The reasons the Court gave in Chadwick for distinguishing the privacy interest associated with cars from that associated with other effects do not explain why the areas in which evidence is usually found (e.g. glove compartments, trunks and so on) are less protected than other private areas which house personal property. More importantly, even if the car and its interior do have a diminished aura of privacy, the fact should not be relevant to whether a warrant is required.

Id.

257 See infra notes 283-307 and accompanying text (using Supreme Court cases regarding subpopulations of high school students to illustrate the way one population can have varying yet legitimate expectations of privacy).

258 See infra notes 283-309 and accompanying text (illustrating the differing expectations of privacy through high school students). 
aware that, due to their status, they should expect less privacy from government intrusions than other students. ${ }^{259}$

There are, however, other individuals who by virtue of their special status deserve less privacy and should be aware they have less privacy than other citizens. ${ }^{260}$ The Supreme Court has made clear that probationers, parolees, and those in custodial facilities fall into this category. ${ }^{261}$ In Morrrissey v. Brewer, the Court asserted that parolees "do not enjoy the absolute liberty to which every citizen is entitled."262 In United States $v$. Knights, the Court held that as a probationer, Knights, had a "significantly diminished expectation of privacy," and therefore a search of his home was permissible with reasonable suspicion but without probable cause or a warrant. ${ }^{263}$ In Samson v. California, the Court dealt with the issue of whether parolees could be searched when the government possessed neither reasonable suspicion nor a warrant. ${ }^{264}$ In permitting such searches, the Court observed that because they enjoy even less freedom than probationers, parolees have an expectation of privacy that is reduced even more than that of probationers. 265 The Samson Court noted the restrictions on liberty that attend to parolees in California and the state law declaring that a parolee is in the "legal custody of the Department of Corrections." 266 The Court concluded that due to such restrictions, parolees "have severely diminished expectations of privacy by virtue of their status alone." 267

The holdings in Knights and Samson make clear that due to the relative loss of liberty that probationers, and to a greater extent parolees,

\footnotetext{
259 This awareness element was described in Marshall v. Barlow's Inc., wherein the Supreme Court distinguished between government inspections of businesses which are pervasively or closely regulated, such as those that sell liquor or firearms, and others such as Barlow's plumbing and electrical installation businesses, regarding the Fourth Amendment reasonableness of such inspections. 436 U.S. 307, 314-15 (1978). This distinction is based on the diminished expectation of the former because such businesses are aware of the heightened government scrutiny of their operations, through such things as periodic inspections, and in effect consent to them. Id. at 313 .

260 See generally Samson v. California, 547 U.S. 843, 847 (2006) (incorporating parolees); United States v. Knights, 534 U.S. 112, 117 (2001) (regarding probationers); Hudson v. Palmer, 468 U.S. 517, 538-39 (1984) (addressing those in custody).

261 See infra notes 262-67 and accompanying text (discussing cases that highlight these individuals).

262408 U.S. 471, 480 (1972) (quoted in Knights, 534 U.S. at 120).

263 Knights, 534 U.S. at $119-20$.

264 Samson, 547 U.S. at 847.

265 See id. at 850 (explaining that parolees are only permitted to leave prison on parole if they agree to follow severe restrictions imposed, and they are typically subjected to great supervision while on parole).

266 Id. at 851 (emphasis added).

267 Id. at 852
} 
Valparaiso University Law Review, Vol. 49, N0. 3 [2015], Art. 8

experience, they are on a continuum regarding a diminished expectation of privacy. This diminished expectation of privacy due to the relative loss of liberty of a parolee played a large role in the Court's decision that Samson could be subjected to a full-blown search without the presence of individualized suspicion. ${ }^{268}$ Still, even though freedom is restricted in the ways described above, probationers and parolees go about their everyday business largely free of government involvement and control. ${ }^{269}$ Virtually none of the activity of one who has been arrested and in a full custodial facility is similarly free of government involvement and control. ${ }^{270}$ Therefore, it would seem beyond dispute that an arrestee under the near total government control of a jail or prison has even less of an expectation of privacy than that of a parolee.

Interestingly, the dissent of Justice Stevens in Samson makes a similar point regarding an expectation of privacy. ${ }^{271}$ In articulating his disagreement with the majority holding that Samson had no expectation of privacy, Justice Stevens argues that there is a difference between the status of a parolee or a probationer and that of a prisoner. ${ }^{272}$ "A parolee, like a probationer, is set free in the world subject to restrictions intended to facilitate supervision and guard against antisocial behavior."273 One who is arrested and confined to a total custody facility such as a jail or prison has not been set free and therefore would seem again to have a lower expectation of privacy than a parolee or probationer. ${ }^{274}$

Although they have not been convicted of crimes and are often not usually confined in prisons designed to hold those already convicted, arrestees in custodial facilities, such as jails, are deprived of their freedoms in ways similar to those who are confined in prisons. ${ }^{275}$ In a

\footnotetext{
268 See id. (examining the totality of the circumstances involved in the case).

269 See id. at 861 (Stevens, J., dissenting) (acknowledging that parolees and probationers are able to live freely under certain restrictions but with much less supervision and restraints than those imposed in prison).

270 See Samson, 547 U.S. at 862 (citing Hudson v. Palmer, 468 U.S. 517, 527 (1984)) (Stevens, J., dissenting) (illustrating the differing expectations of privacy for parolees and prisoners by acknowledging that prisoners traditionally held no right to privacy under the Fourth Amendment because of the states' need to implement institutional safeguards in all prisons).

271 See id. at 861-64 (illustrating a lessened expectation of privacy for both prisoners and parolees).

$272 \quad I d$.

$273 \quad I d$. at 861.

274 See generally id. (distinguishing those who are set free from those in custody).

275 See generally Florence v. Bd. of Chosen Freeholders, 132 S. Ct. 1510, 1511 (2012) (holding that search procedures at county jails struck a reasonable balance between inmate privacy and the needs of the institution); Bell v. Wolfish, 441 U.S. 520, 521 (1979) (finding that maintaining security and preserving discipline are essential goals that may require limitation of constitutional rights); Lanza v. New York, 370 U.S. 139, 143-44 (1962) (holding
} 
series of cases, the Supreme Court has held that those detained in such custodial institutions have significantly diminished expectations of privacy. ${ }^{276}$ Perhaps the most definitive of those holdings was the Court's relatively recent decision in Florence v. Board of Chosen Freeholders of the County of Burlington.277 Florence was arrested and taken to a county detention center for failing to appear at a hearing regarding a warrant, which incorrectly alleged that he failed to pay a fine.278 Despite the relatively minor nature of what he was arrested for, Florence was subject to a full body search upon his entry into the county detention facility. ${ }^{279}$ The officers at the facility had Florence disrobe and then subjected him to a search that included an inspection of the most private areas of his body. ${ }^{280}$ They executed this search absent any suspicion that Florence might have been carrying items that are prohibited in the facility. ${ }^{281}$ The Court found the search here to be compliant with the Fourth Amendment in part because the conditions and security needs of the institution result in arrestees detained in custodial institutions having a significantly reduced expectation of privacy. .82

Some have characterized the holding in Florence as being distinguishable from issues related to taking DNA samples from arrestees because the purpose and nature of the search in Florence was consistent with the reason for the diminished expectation of privacy of arrestees-institutional security.283 These courts and commentators

\footnotetext{
that a public jail does not share the same privacy attributes as a home or office under the Fourth Amendment); Hudson, 468 U.S. at 527 (holding that an inmate had no reasonable expectation of privacy in his prison cell).

276 See infra note 277 and accompanying text (introducing case law regarding individuals in custodial institutions). In permitting the search and confiscation of a prisoner's private effects without individualized suspicion in Hudson, the Court held that prisoners have no expectation of privacy and noted, "a prison shares none of the attributes of privacy of a home, an automobile, an office or a hotel room." Hudson, 468 U.S. at 527. Detention facilities similarly share none of these privacy attributes. Id. (quoting Lanza, 370 U.S. at 143-44).

277 Florence, $132 \mathrm{~S}$. Ct. at 1510. The Court held that a detainee's Fourth Amendment rights were not violated when he was subjected to invasive searches before entering the jail. Id. at 1510-11.

278 Id. at 1514

279 Id.

$280 \quad I d$.

$281 \quad I d$

282 Florence, 132 S. Ct. at 1518.

283 See Friedman v. Boucher, 580 F.3d. 847, 856-57 (9th Cir. 2007) (holding that pre-trial detainee status did not warrant a DNA swab); United States v. Mitchell, 652 F.3d 387, 422 (3d Cir. 2011) (Rendell, J., dissenting) (stating that a statute permitting suspicionless DNA collection from arrestees did not violate the Fourth Amendment); Julian Ellis, Florence v. Bd. of Chosen Freeholders: The Resurrection of Bell v. Wolfish and the Questions to Follow, 90
} 
point out that obtaining samples of DNA to compare with DNA samples left at crime scenes has no relationship to the security of the institution in which arrestees, such as King, are housed.284 The majority in King II, however, asserted that establishing an individual's identity, particularly an arrestee's criminal record, is of utmost importance in maintaining the security of a custodial facility. ${ }^{285}$ The Court noted that establishing certainty about identity, through the most accurate measure possible, informs security related decisions about the location and conditions of an inmate's housing. 286

Still, as discussed below, it is likely more accurate to say that the primary purpose of laws permitting the taking of DNA samples from arrestees is to compare the samples to those found at crime scenes and thus determine if there is a link between the arrestee and those crimes. ${ }^{287}$ Therefore, it is important to address the above argument regarding the relative disconnect between this purpose for obtaining the DNA samples of arrestees and the government's need for institutional security that results in arrestees having a diminished expectation of privacy. ${ }^{288}$ In other words, is such a link necessary before courts can find that a diminished expectation of privacy is a significant factor in the balancing test used to determine the legality under the Fourth Amendment for government searches and seizures performed without individualized suspicion?

The Supreme Court cases most instructive in this regard are those that dealt with drug testing of sub-populations of high school students. ${ }^{289}$ What is especially relevant in these cases is not the expectation of privacy of all high school students, which is diminished due to the supervisory and tutelary role the school plays in the lives of

DENV. U. L. REV. 559, 573 (2012) (examining the applicability and exceptions of the Florence decision).

284 Friedman, 580 F.3d at 856-57; Mitchell, 652 F.3d at 422

285 See Maryland v. King (King II), 133 S. Ct. 1958, 1971 (2013) (“A suspect's criminal history is a critical part of his identity that officers should know when processing him for detention. It is a common occurrence that [p]eople detained for minor offenses can turn out to be the most devious and dangerous criminals.").

286 Id. at 1971-75.

287 See supra note 285 and accompanying text (discussing the decision in Maryland $v$. King).

${ }^{288}$ See generally King II, 133 S. Ct. at 1978 (demonstrating that the privacy expectations of those in custody is greatly diminished).

289 See Vernonia Sch. Dist. 47J v. Acton, 515 U.S. 646, 646 (1995) (holding that student athlete drug testing policy did not violate students' federal or state constitutional rights to be free from unreasonable searches); see also Bd. of Educ. of Indep. Sch. Dist. No. 92 of Pottawatomie Cnty. v. Earls, 536 U.S. 822, 822 (2002) (holding that drug testing students participating in competitive extra-curricular activities was reasonable). 
its students. ${ }^{290}$ Instead, it is the claimed additional reduction in the expectation of privacy of sub-populations in schools that allows the government to drug test these particular groups without individualized suspicion. ${ }^{291}$ When approving the drug testing of students who were on the football team of an Oregon high school without any individualized suspicion of drug use in Vernonia School Dist. 47J v. Acton, the Court offered two reasons why the members of the team had a diminished expectation of privacy when compared to other students. ${ }^{292}$ The first reason offered by the Court is related to the "element of communal undress inherent in athletic participation." 293 The Court here referred to the "suiting up" and "showering" of the players as reasons why "school sports are not for the bashful." 294 The purpose of compelling high school athletes to provide urine samples is to see if they have ingested illegal drugs. ${ }^{295}$ Whether this purpose relates to the diminished expectation of privacy stemming from the supposed lack of bashfulness apparently required for high school students to play football is debatable. ${ }^{296}$

The second reason offered by the Court in Vernonia as to why high school athletes have a diminished expectation of privacy however leaves no doubt about its lack of connection to the purpose for the search and seizure involved with the drug testing of urine samples. ${ }^{297}$ According to the Court, this has to do with the higher degree of regulation students supposedly agree to by going out for a high school sports team. ${ }^{298}$ The Court noted that:

$$
\begin{aligned}
& \text { They must submit to a preseason physical } \\
& \text { exam[,]... they must acquire adequate insurance } \\
& \text { coverage or sign an insurance waiver, maintain a } \\
& \text { minimum grade point average, and comply with any } \\
& \text { "rules of conduct, dress, training hours and related } \\
& \text { matters as may be established for each sport by the head }
\end{aligned}
$$

\footnotetext{
290 See Vernonia Sch. Dist. 47J, 515 U.S. at 655-56 (finding that random drug testing of student-athletes did not violate the Fourth Amendment).

291 See infra notes 292, 302 and accompanying text (listing the cases involving high school populations).

292 Vernonia Sch. Dist. 47J, 515 U.S. at 655-56.

$293 \quad I d$. at 657.

294 Id.

295 Id. at 648-52.

296 See generally id. at 657 (addressing the lack of bashfulness in student-athletes).

297 See generally id. (reasoning that student-athletes assent to the searches as a condition of playing sports).

298 Vernonia Sch. Dist. 47J, 515 U.S. at 657.
} 
Valparaiso University Law Review, Vol. 49, N0. 3 [2015], Art. 8

coach and athletic director with the principal's approval." 299

As the Court further noted, "[s]omewhat like adults who choose to participate in a 'closely regulated industry,' students who voluntarily participate in school athletics have reason to expect intrusions upon normal rights and privileges, including privacy." 300 While the regulations that arrestees are subjected to are, of course, not voluntary like they are with students who make the choice to play football, arrestees entering jails have far more reason to expect far more intense intrusions on their rights to privacy. ${ }^{301}$ Most importantly, there is no connection between the purpose of the search and seizure, drug testing urine, and the supposed reduction in privacy stemming from requirements such as purchasing insurance, maintaining a minimum GPA, and following rules of conduct and dress directed by team coaches.

In Board of Education of Independent School District No. 92 of Pottawatomie County v. Earls, the Court confronted issues related to the constitutionality of drug testing all students who participated in all extracurricular activities. ${ }^{302}$ The Court first minimized the significance of the point it had made in Vernonia about the diminished expectation of privacy of athletes deriving to some degree from the fact that they were subjected to frequent physicals and communal undress. ${ }^{303}$ In doing so, it made even clearer the relative unimportance of the connection between the government need that results in a group's diminished expectation of privacy and the purpose of the search or seizure that is permitted in part because of that diminution. 304 The Court's conclusion was that because all students participating in extracurricular activities are subject to certain regulations beyond what non-participating students are subjected to, the privacy of these students is further diminished. ${ }^{305}$ In fact, the

\footnotetext{
$299 \quad I d$.

$300 \quad I d$.

301 Maryland v. King (King II), 133 S. Ct. 1958, 1970-71 (2013).

302 See Bd. of Educ. of Indep. Sch. Dist. No. 92 of Pottawatomie Cnty. v. Earls, 536 U.S. 822, 822 (2002) (upholding the constitutionality of drug testing of students in extracurricular activities). policies). It is reasonable to question the Court's assertion that all students participating in extracurricular activities have a diminished expectation of privacy thus allowing for the drug testing of their urine without individualized suspicion or a warrant. Bd. of Educ. of Indep. Sch. Dist. No. 92 of Pottawatomie Cnty., 536 U.S. at 822. Regardless, it is difficult to understand how anyone could claim that such students have any less of an expectation of privacy than those confined to custodial institutions after being arrested for serious felonies. Taking the comparison of the two forms of testing farther, it would seem that
} 
Court apparently did not feel the need to enumerate what those restrictions on freedom were with respect to each extracurricular group, thus emphasizing that what matters is not the specific reasons for the restrictions or their connection to the particular search or seizure at issue, but the fact that the restrictions in some way create a diminished expectation of privacy. ${ }^{306}$ This diminution in the privacy expectation of students participating in extracurricular activities while not related to the need to drug test them, is according the Court, a significant factor in allowing this search and seizure without individualized suspicion. ${ }^{307}$

What is beyond dispute is that the extent of the intrusion involved in taking a swab from the cheek of a detainee is far less than that involved in the full body search that the Court permitted in Florence. ${ }^{308}$ It would be something of an anomaly to determine that the highly intrusive full body search of someone detained for even a minor offense is permissible under the Fourth Amendment but a far less intrusive search (when the uses of the sample are limited as in the Maryland statute at issue in King II) done only for those arrested for serious crimes is not. ${ }^{309}$ There is then at least one clear conclusion that can be drawn from previous holdings of the Supreme Court regarding the balancing test to determine the Fourth Amendment reasonableness of searches done of arrestees in custodial institutions. 310 Due to the significantly diminished expectations of privacy of such detainees, limited non-arbitrary searches and seizures affected without individualized suspicion are permitted to accomplish appropriate governmental purposes. ${ }^{311}$

\footnotetext{
compelling teenagers to urinate, sometimes while being observed to insure the integrity of the samples provided, is more embarrassing than swabbing the cheeks for DNA. Such embarrassment is relevant to the extent of the government intrusion for Fourth Amendment purposes. Vernonia Sch. Dist. 47J, 515 U.S. at 650; see also Skinner v. Ry. Labor Execs. Ass'n, 489 U.S. 602, 655 n.7 (1989) (addressing random drug testing among railroad employees). Of course urine samples, like DNA, can be used for purposes beyond just detecting the presence of illegal drugs; however, most drug testing programs provide protections against abuse of the data acquired through the tests, but not always with the strong punitive measures of the Maryland DNA statute at issue in King.

306 Bd. of Educ. of Indep. Sch. Dist. No. 92 of Pottawatomie Cnty., 536 U.S. at 823.

$307 \quad$ Id. at 832

308 Florence v. Bd. of Chosen Freeholders, 132 S. Ct. 1510, 1514 (2012).

309 See Maryland v. King (King II), 133 S. Ct. 1958, 1970 (2013) (conveying that those booked in custody undergo extensive physical examinations).

310 See supra Part V (elaborating on Supreme Court holdings regarding the reasonableness test).

311 See King II, 133 S. Ct. at 1980 (validating extensive searches of detainees).
} 
Valparaiso University Law Review, Vol. 49, No. 3 [2015], Art. 8

\section{PRIMARy PURPOSE TEST}

Courts use the primary purpose test to determine reasonableness under the Fourth Amendment. ${ }^{312}$ First, Part VII.A assesses the use of the primary purpose test in regards to DNA testing. ${ }^{313}$ Second, Part VII.B explains why the test is unclear in its definition and inconsistent in its application. ${ }^{314}$ Last, Part VII.C suggests that the primary purpose test protects the wrong people. ${ }^{315}$

\section{A. The Primary Purpose Test as it Relates to the DNA Testing of Arrestees}

The principle Fourth Amendment barrier to the government's ability to take and test DNA swabs from arrestees appears to be what has been referred to as the primary purpose test. ${ }^{316}$ That is, for searches and seizures performed without individualized suspicion, the primary purpose of such a Fourth Amendment intrusion must be other than "ordinary criminal wrongdoing." 317 In his dissenting opinion in King II, for example, Justice Scalia asserted that while the Court had approved suspicionless intrusions into interests protected by the Fourth Amendment, those intrusions were not when the "primary purpose was to detect evidence of criminal wrongdoing." 318 The "appropriate" noncriminal investigatory purposes of such suspicionless searches and seizures have been variously categorized by courts as "administrative," "special needs," or falling within some subcategory often referred to as intrusions based on "general reasonableness." 319 Regardless of what they are called, the definition, interpretation, and application of such approaches to suspicionless searches and seizures has been inconsistent, confusing, and often not based on the real values behind the Fourth Amendment. ${ }^{320}$ This Part also examines the meaning or meanings of the

\footnotetext{
312 See generally City of Indianapolis v. Edmond, 531 U.S. 32, 53 (2000) (elaborating on the primary purpose test).

313 See infra Part VII.A (applying the primary purpose test to DNA testing).

314 See infra Part VII.B (insinuating that the test is unclear).

315 See infra Part VII.C (suggesting there is no good reason that the primary purpose test may protect the wrong people).

316 Maryland v. King (King II), 133 S. Ct. 1958, 1978 (2013).

317 Id. (quoting Edmond, 531 U.S. at 38).

318 Id. at 1981-82.

319 See Camara v. Municipal Ct. of San Francisco, 387 U.S. 523, 534 (1967) (stating "administrative" searches are significant intrusions on Fourth Amendment interests); see also Vernonia Sch. Dist. 47J v. Acton, 515 U.S. 646, 653 (1995) (discussing "special needs" searches); Roe v. Texas Dep't of Protective \& Regulatory Servs., 299 F.3d 395, 405 (5th Cir. 2002) (referring to the Supreme Court's application of a "general reasonableness" test that was articulated in Wyman v. James, 400 U.S. 309, 318 (1971)).

320 See infra Part VII.A (elaborating on the inconsistencies in primary purpose test).
} 
primary purpose test as formulated by the Supreme Court and explores whether the primary purpose of a suspicionless search or seizure should be an integral factor in a determination of its legality under the Fourth Amendment. ${ }^{321}$

The government in King II identified two purposes for taking DNA samples from those arrested for serious crimes. ${ }^{322}$ As discussed above, the first purpose is to assist in the accurate identification of arrestees. ${ }^{323}$ This is akin to the use of fingerprints in allowing the authorities to learn, among other things, if the arrestee is who he claims he is, whether he has a criminal record, and whether there are outstanding warrants against him. ${ }^{324}$ It is critical to have such information for purposes related, but not limited, to the nature of the charges to be brought, bail considerations, and sentencing factors. ${ }^{325}$ The Court in King II spent much of its opinion enumerating and evaluating the government's interests in establishing the arrestee's identification and use of DNA testing to do so. ${ }^{326}$ While Justice Scalia's dissent focused as well on this purpose for testing, he mocked the majority's claim that identification was the primary purpose of the testing. ${ }^{327}$ Justice Scalia concluded part of his dissent by saying "it is safe to say that if the Court's identification theory is not wrong, there is no such thing as error." 328

Fingerprints remain the principle method of establishing the identification of arrestees, but because there may be omissions in certain fingerprint-based reports of an arrestee's prior record or at times just to confirm his identity, courts have accepted this as a proper government

\footnotetext{
321 See infra Part VII (discussing the primary purpose test and its potential place in the Fourth Amendment).

322 King II, 133 S. Ct. at $1975-76$.

323 Id. (quoting Hiibel v. Sixth Judicial Dist. Court of Nev., 542 U.S. 177, 191 (2004)).

324 Id. at 1972.

325 Id. When a person has been previously convicted of a crime, the charge he faces when accused again of the same crime can be a more serious. C.f. MD. CODE ANN., CRIM. LAW $\S 5-607$ (West 2006). The purpose of setting bail is to insure the defendant's appearance at all court proceedings up to trial. King II, 133 S. Ct. at 1972-73. A secondary purpose is to assess the danger to the community if the defendant is freed pending trial. Id. at 1973. Whether the defendant has a criminal record and what crimes he has been convicted of play an important role in that determination. Id. Finally, when a judge decides on what sentence a defendant should receive, the severity of the sentence is often based in large part upon the defendant's criminal history. Id. In certain instances, prior convictions may permit or require a longer prison sentence. C.f. MD. CODE ANN., CRIM. LAW § 14-101 (West 2013).

326 King II, 133 S. Ct. at 1972-74.

327 Id. at $1983-84$.

$328 \quad$ Id. at 1986.
} 
Valparaiso University Law Review, Vol. 49, N0. 3 [2015], Art. 8

interest in conducting such DNA testing. ${ }^{329}$ Some courts have used the fact that DNA testing can establish or confirm the identity of an arrestee as a way around the primary purpose test. ${ }^{330}$ The purpose of this identification function for DNA testing is administrative in nature and not focused on investigating ordinary criminal wrongdoing. ${ }^{331}$ If this is the primary purpose of DNA testing of arrestees, then the Supreme Court holdings which require individualized suspicion for such government investigatory searches or seizures would not be applicable to the DNA testing of arrestees. ${ }^{332}$ In King II, the majority opinion argued that identification was an important purpose of DNA testing, and therefore individualized suspicion was not necessary to conduct the tests, but the manner in which the Court discussed what it meant by identification was somewhat confusing and opened the door to the criticism in Justice Scalia's dissent. 333

Courts that make the above argument are not incorrect in the claim that DNA testing can and does get used for identification purposes. ${ }^{334}$ Those courts, however, are being somewhat disingenuous in making the assertion that this should be sufficient to avoid the strictures of the primary purpose test. States that use such DNA testing do not limit the results to mere arrestee identification, and in fact, most acknowledge that

329 See Dist. Attorney's Office Third Judicial Dist. v. Osborne, 557 U.S. 52, 62 (2009) (recognizing the value of DNA evidence); Haskell v. Harris, 669 F.3d 1049, 1060 (9th Cir. 2012) (expressing that DNA evidence is more reliable than fingerprinting); United States v. Amerson, 483 F.3d 73, 85 (2d Cir. 2007) (noting that DNA is a more reliable means of identification); Maryland v. Raines, 857 A.2d 19, 52 (Md. 2004) (Wilner, J., concurring) (asserting that DNA is more reliable and serves the same governmental interest that justifies fingerprints). See generally Jennifer L. Mnookin, The Courts, The Nas, and the Future of Forensic Science, 75 BROOK. L. REV. 1209, 1243-44 (2010) (discounting the accuracy of fingerprinting).

330 See Green v. Berge, 354 F.3d 675, 678 (7th Cir. 2004) (identifying that the primary purpose was not for evidence but reliable proof of identification); see also Jenkins v. United States, 75 A.3d 174, 177 (D.C. 2013) (Thompson, J., dissenting) (noting that DNA was used to identify the accused).

331 King II, 133 S. Ct. 1970.

332 When the Supreme Court held that the drug interdiction checkpoints established by the Indianapolis police violated the Fourth Amendment, because cars were seized without individualized suspicion, the Court based its opinion on the conclusion that the primary purpose of these checkpoints was "to uncover evidence of ordinary criminal wrongdoing." City of Indianapolis v. Edmond, 531 U.S. 32, 41-42 (2000). In so doing, the Edmond Court discussed prior Supreme Court cases in which the primary purpose of the search or seizure was crucial to determining whether individualized suspicion was required to comply with the Fourth Amendment. Id. at 37-40.

333 See King II, 133 S. Ct. at 1970, 1983 (arguing that DNA identification of arrestees is important and criticizing the process of identifying arrestees).

334 See generally Green, 354 F.3d at 678 (discussing identification as a primary purpose); Jenkins, 75 A.3d at 177 (conveying that the accused was identified through DNA). 
the primary purpose of taking DNA swabs from arrestees is to compare the DNA to similar evidence left at the scenes of serious crimes to determine if there is a match. ${ }^{335}$ The Maryland statute at issue in King II allows for precisely that. ${ }^{336}$ It is unlikely that law enforcement agencies would incur the costs associated with DNA testing merely to catch the relatively few mistakes in identifying suspects that occur from fingerprint analysis. ${ }^{337}$ Additionally, as Justice Scalia argues in his dissent in King II, the amount of time needed to get the results from DNA testing would make such testing largely unhelpful in accomplishing the benefits of having an accurate identification of the arrestee. $^{338}$ It is far more reasonable to assume that because a DNA match is a powerful tool that can help solve serious unsolved crimes, as both the majority and dissenting opinions in King II agree, law enforcement agencies are anxious to test at least those arrested for

335 DNA Sample Collection from Arrestees, NAT'L INST. JUSTICE (Dec. 7, 2012), http://www.nij.gov/topics/forensics/evidence/dna/pages/collection-from-arrestees. aspx, archived at http:// perma.cc/Y9GM-5GVY. In his dissent in King II, Justice Scalia notes in this regard:

That is certainly how everyone has always understood the Maryland Act until today. The Governor of Maryland, in commenting on our decision to hear this case, said that he was glad, because "[a]llowing law enforcement to collect DNA samples... is absolutely critical to our efforts to continue driving down crime," and "bolsters our efforts to resolve open investigations and bring them to a resolution. The attorney general of Maryland remarked that he "look[ed] forward to the opportunity to defend this important crime-fighting tool," and praised the DNA database for helping to "bring to justice violent perpetrators." Even this Court's order staying the decision below states that the statute "provides a valuable tool for investigating unsolved crimes and thereby helping to remove violent offenders from the general population" - with, unsurprisingly, no mention of identity.

King II, 133 S. Ct. at 1985 (Scalia, J., dissenting) (citations omitted).

336 See King II, 133 S. Ct. at 1985 (discussing the statute). MD. CODE AnN., Public SAFETY $\S 2-505$ (2011). “(a) To the extent fiscal resources are available, DNA samples shall be collected and tested: (1) to analyze and type the genetic markers contained in or derived from the DNA samples; (2) as part of an official investigation into a crime." Id.

337 For example, in Maryland in 2013, the year the Supreme Court decided King II, approximately 5000 Maryland samples were added to the national DNA database. Maryland Study on Preventable Crimes, supra note 231. If the cost of taking and testing each sample ranges from $\$ 35$ to $\$ 50$, the total cost for that year in Maryland would be from $\$ 175,000$ to $\$ 250,000$. Id . It seems unlikely a state would incur that expense just to confirm what fingerprint testing already reveals and providing such information for only the limited amount of felony arrests that permit such testing. Eric Ferkenhoff \& Maurice Possley, DNA Tests Urged for All Arrestees, CHI. TRIB. (Feb. 16, 2002), available at http://articles.chicagotribune.com/2002-02-16/news/0202160181_1_dna-samples-dnaevidence-felony-arrests, archived at http:/ / perma.cc/2J53-TBWM.

338 King II, 133 S. Ct. at 1983-85 (Scalia, J., dissenting). 
serious crimes to determine if they are connected to other such crimes.339 Therefore, the primary purpose of DNA testing of arrestees is very likely that of criminal investigation. ${ }^{340}$ Contrary to the view of courts that have found the DNA testing of arrestees to be violative of the Fourth Amendment however, such a conclusion about the primary purpose of such testing should be the beginning, not the end, of the inquiry about the constitutionality of this procedure. ${ }^{341}$

There are several significant problems that attend the use of the primary purpose test as the determining factor regarding whether government searches and seizures require the presence of individualized suspicion. The definition of the test is unclear and courts have added to this confusion in attempting to apply the test. The acceptance of the test leads to better Fourth Amendment protection for those engaged in criminal activity than those who are not. Another problem is that courts can and do evade the test by creating subcategories for searches and seizures which allows the use of general reasonableness in lieu of individualized suspicion regardless of the primary purpose of the intrusion. ${ }^{342}$

\section{B. The Test is Unclear in its Definition and Inconsistent in its Application}

The case often cited for the use of the primary purpose test as the determining factor in whether individualized suspicion is necessary for a Fourth Amendment intrusion is City of Indianapolis v. Edmond.343 In Edmond, the Supreme Court held that a motor vehicle checkpoint designed to interdict the flow of illegal drugs violated the Fourth Amendment because it did not require individualized suspicion to seize a vehicle. ${ }^{344}$ The Court acknowledged, as previous cases had made clear, that individualized suspicion was not an "irreducible component of reasonableness[,]" the ultimate test of Fourth Amendment compliance,

339 Id. at 1973; id. at 1989 (Scalia, J., dissenting).

340 Id. at 1983-85 (addressing law enforcement's focus on testing DNA to solve other crimes).

341 United States v. Davis, 690 F.3d 226, 232-33 (4th Cir. 2012); People v. Buza, 129 Cal. Rptr. 3d 753, 783 (Ct. App. 2011); State v. Martin, 955 A.2d 1144, 1166 (Vt. 2008) (Johnson, J., dissenting); see Julie Rikelman, Justifying Forcible DNA Testing Schemes Under the Special Needs Exception to the Fourth Amendment: A Dangerous Precedent, 59 BAYLOR L. REV. 41, 7576 (2007) (concluding that DNA testing of arrestees cannot be justified under Fourth Amendment).

342 See Edwin J. Butterfoss, A Suspicionless Search and Seizure Quagmire: The Supreme Court Revives the Pretext Doctrine and Creates Another Fine Fourth Amendment Mess, 40 CREIGHTON L. REV. 419, 422-23 (2007) (recognizing that the Court has been inconsistent with treatment of searches due to the ambiguity of the primary purpose test).

343531 U.S. 32,37 (2000).

344 Id. at $45-48$. 
but asserted that its absence was permitted in only limited circumstances. 345 The Court referred to these circumstances as special needs beyond normal enforcement of criminal law. 346 Specifically, the Court identified such special needs in prior holdings dealing with drug testing of students and others, the search of a business dealing in the sale of used car parts, border area checkpoints to detect the presence of undocumented aliens and sobriety checkpoints. ${ }^{347}$ Referring to the checkpoint cases specifically, but including all the special needs cases, the Edmond Court wrote, "[i]n none of these cases, however, did we indicate approval of a checkpoint program whose primary purpose was to detect evidence of ordinary criminal wrongdoing." 348

One iteration of the primary purpose test is its use in allowing for the search of closely regulated businesses without the traditional probable cause and warrant requirements. ${ }^{349}$ Due to the fact that some businesses are highly regulated, they are deemed to have a diminished expectation of privacy when it comes to their protection under the Fourth Amendment regarding government intrusions. ${ }^{350}$ In United States v. Biswell, for example, the Court permitted the warrantless search of a pawnshop licensed to sell firearms in part because the highly regulated nature of the firearms industry made such warrantless searches reasonable. ${ }^{351}$ In Marshall v. Barlow's Inc., the Court made an even stronger statement on the subject writing that "certain industries have such a history of government oversight that no reasonable expectation of privacy could exist for the proprietor over the stock of such an enterprise." 352

Nine years after the Court wrote the above quote, it made clear that for the government to take advantage of the "closely regulated" business

\footnotetext{
$345 \quad I d$.

346 Id. In some of the cases in which the Court has excused this requirement for individualized suspicion, terms other than "special needs" have been used, but the essence of the principle was the same-that the primary purpose of the search or seizure was other than routine enforcement of the criminal laws. Id. at 37-38.

347 Bd. of Educ. of Indep. Sch. Dist. No. 92 of Pottawatomie Cnty. v. Earls, 536 U.S. 822, 830-32 (2002); Vernonia Sch. Dist. 47J v. Acton, 515 U.S. 646, 655-56 (1995); Skinner v. Ry. Labor Execs. Ass'n, 489 U.S. 602, 634 (1989) (regarding railroad workers involved in accidents); Nat'l Treasury Emps. Union v. Von Raab, 489 U.S. 65, 677 (1989); New York v. Burger, 482 U.S. 691, 701 (1987); United States v. Martinez-Fuerte, 428 U.S. 543, 559 (1976); Mich. Dep't of State Police v. Sitz, 496 U.S. 444, 452-53 (1990).

348 Edmond, 531 U.S. at 38.

349 Burger, 482 U.S. at 719.

$350 \quad$ Id.

351406 U.S. 311,317 (1972)

352436 U.S. 307, 313 (1978). Although the Court in Marshall held that merely because a business operates in interstate commerce does not mean it falls within the realm of being pervasively regulated. Id. at 314; Burger, 482 U.S. at 719.
} 
Valparaiso University Law Review, Vol. 49, N0. 3 [2015], Art. 8

doctrine, there must be a "substantial government interest" in regulating the industry that goes beyond merely enforcing criminal laws. ${ }^{353}$ In New York v. Burger, the Court held that the warrantless search of a junkyard dealing in the dismantling and selling of used automobile parts falls within the "closely regulated business" doctrine and therefore does not violate the Fourth Amendment. ${ }^{354}$ In so holding, the Court reversed the judgment of the New York Court of Appeals, that the inspection conducted by police officers was to ferret out crime and not to "enforce a comprehensive regulatory scheme." 355 The Supreme Court rejected the New York court's analysis and conclusion regarding the nature of the inspections. ${ }^{356}$ The New York Court had held that because they were carried out by police officers and not regulatory agency officials, and that violations could and would result in criminal sanctions, the government's claim that this was an administrative inspection was merely a ruse for enforcing the criminal law. ${ }^{357}$

The Court in Burger held that the state may "address a major social problem both by way of an administrative scheme and through penal sanctions." 358 Omitted from the Burger decision was whether the Court considered the regulatory or criminal investigation purpose to be the primary one. ${ }^{359}$ This raises the question as to whether the non-criminal purpose of the test must indeed be primary or whether its mere existence is sufficient to avoid the requirement of individualized suspicion. Instead, the Court spoke of the criminal and regulatory investigations having perhaps the same "ultimate" purpose but different "subsidiary" purposes - a difference in this context similar to that between ends and means. ${ }^{360}$ Here, the subsidiary regulatory purpose was said to be the regulation of the automobile dismantling industry to ensure that the businesses are legitimate and that stolen vehicle parts passing through junkyards can be identified. ${ }^{361}$ The subsidiary purpose of the penal law

\footnotetext{
353 Burger, 482 U.S. at 700, 702.

354 See id. at 701, 707 (taking note of the Court's holding that the "closely related" business doctrine applies to the regulation of junkyards).

355 See id. at 697-98 (discussing that the Court's holding that the regulation of junkyards falls within the parameters of the "closely related" business doctrine overturned the lower New York Court of Appeals decision).

356 See id. at 712 (noting that the New York court found the statute a violation of the Fourth Amendment).

357 See id. (holding that the search falls within the administrative inspection exception of "closely related business," rather than a violation of the Fourth Amendment).

$358 \quad$ Id. at 712 .

359 See generally Burger, 482 U.S. at 691 (negating any clarification).

360 See id. at 713 (discussing the differences and similarities between the "ultimate" and "subsidiary" purposes).

361 See id. at 713-14 (examining the purpose behind the legislation).
} 
here is to punish for possession of stolen property. ${ }^{362}$ While the ultimate purpose of both may be to address the "major social problem" involved here, the Court claimed this difference in subsidiary purposes allowed for the use of the "closely regulated business" justification for the warrantless search conducted. ${ }^{363}$

The Court in Burger made the definition of the primary purpose test more confusing by examining the search in terms of two different subsidiary purposes, leading to an ultimate purpose that targeted a major social problem. ${ }^{364}$ In Ferguson v. Charleston, the Court introduced yet another method of approaching the primary purpose test dealing with subsidiary and ultimate purposes. ${ }^{365}$ Ferguson held that tests of pregnant women designed to deter such women from using drugs because of the resulting harm, both to them and their unborn children, violated the Fourth Amendment. ${ }^{366}$ The Court reasoned that the ultimate goal of the testing may have been therapeutic - that is to get women into drug rehabilitation clinics and deter other pregnant women from using drugs. ${ }^{367}$ However, the means, the use of law enforcement personnel and the criminal justice system, demonstrated the primary purpose of the program was more penal than administrative or special need. 368 Of course, the search in Burger was also conducted by police and ultimately enforced through the criminal justice system, but the Ferguson Court distinguished Burger due to the diminished expectation of privacy of the automobile parts dealership in that case. ${ }^{369}$

Seemingly even more on point to the issues in Ferguson, were the Supreme Court's previous decisions upholding the constitutionality of sobriety checkpoints and drug testing among certain other groups conducted without individualized suspicion. ${ }^{370}$ A primary purpose of

\footnotetext{
362 See id. at 713 (noting the underlying purpose of the law).

363 See id. at 712-13 (noting that the Court found the "closely regulated" business doctrine applicable because of the differences between the purposes).

$364 \quad I d$. at 712.

365 See Ferguson v. Charleston, 532 U.S. 67, 79 (2001) (holding that "special need" was yet another exception making suspicionless searched constitutional under the Fourth Amendment).

366 Id. at 79.

367 Id.

368 See id. at 82-84 (describing that the primary purpose was not within the administrative or special need exception).

369 See id. at 83-84 n.21 (discussing the Ferguson Court's way of distinguishing the Burger facts).

370 See Mich. Dep't of State Police v. Sitz, 496 U.S. 444, 447 (1990) (holding that sobriety checkpoints were constitutional); Bd. of Educ. of Indep. Sch. Dist. No. 92 of Pottawatomie Cnty. v. Earls, 536 U.S. 822, 838 (2002) (holding that suspiciousness drug testing is constitutional); see also Vernonia Sch. Dist. 47J v. Acton, 515 U.S. 646, 664-65 (1995) (holding that Vernonia's drug testing policy was constitutional because of the decreased expectation
} 
Valparaiso University Law Review, Vol. 49, N0. 3 [2015], Art. 8

sobriety checkpoints is claimed to be deterring motorists from driving while drunk. ${ }^{371}$ In Ferguson, a similar deterrent purpose was at issue. ${ }^{372}$ Also similar to the drug testing in Ferguson was the subsidiary purpose of the government action in sobriety checkpoints, the use of the criminal justice system to achieve those ends. ${ }^{373}$ While in Sitz, the Court regarded the seizures at sobriety checkpoints to be minor intrusions, the Court in Ferguson held that acquiring and testing the urine samples of pregnant women was a significant intrusion. ${ }^{374}$

Yet, the Court allowed the suspicionless taking of urine samples for drug testing purposes in a series of cases beginning with Skinner. ${ }^{375}$ In these cases, the Court held that that the level of intrusion caused by the testing of urine samples was not extensive enough to make the search there unreasonable under the balancing test of the Fourth Amendment. ${ }^{376}$ The next task then for the Court in Ferguson was to distinguish the drug testing there from those previous cases that had permitted such testing without individualized suspicion. ${ }^{377}$

In doing so, the Court in Ferguson offered a distinction that is especially relevant to the determination of how the DNA testing of arrestees should fare under the primary purpose test. ${ }^{378}$ The Court regarded the intrusion in Ferguson as more extensive than in the other

of privacy and the need for the search); see also Nat'l Treasury Emps. Union v. Von Raab, 489 U.S. 656, 663, 666-67, 672 n.2 (1989) (holding that the searches were constitutional because of the substantial government interest); Skinner v. Ry. Labor Execs. Ass'n, 489 U.S. 602, 624 (1989) (holding that that searches were reasonable because the privacy intrusion were minimal and an important government interest was at stake).

371 See Steven Grossman, Sobriety Checkpoints: Roadblocks to Fourth Amendment Protections, 12 AM. J. CRIM. L. 123, 157 n.189 (1984) (discussing the purpose of the roadblocks to arrest drunk drivers).

372 See Ferguson, 532 U.S. at 82-83 (noting the program's ultimate goal).

373 See id. at 83-84 (discussing the search's objective).

374 See Sitz, 496 U.S. at 451-52 (examining the level of intrusiveness of sobriety checkpoints); Ferguson, 532 U.S. at 78 (stating that the drug test was found to be intrusive because of the privacy expectations between a patient and a doctor).

375 See Skinner, 489 U.S. at 624 (holding that suspicionless drug testing was constitutional); see also Vernonia Sch. Dist. 47J, 515 U.S. at 664-65 (holding that Vernonia's drug testing policy was constitutional because of the decreased expectation of privacy and the need for the search); Von Raab, 489 U.S. at 663, 666-67, $672 \mathrm{n} .2$ (holding that the searches were constitutional because of the substantial government interest).

376 See Skinner, 489 U.S. at 617 (finding that the search was reasonable under the Fourth Amendment); see also id. at 621 n.5, 622 n.6 (noting that the Ferguson Court distinguished the extent of the intrusion involved in that case with the lesser intrusion resulting from the drug testing of railroad employees after accidents and certain employees of the United States Customs Service); Von Raab, 489 U.S. at 663, 666-67, 672 n.2 (holding that suspicionless drug testing was constitutional).

377 Ferguson, 532 U.S. at 78.

378 Id. 
drug testing cases because, "[i]n the previous four cases, there was no misunderstanding about the purpose of the test or the potential use of the test results, and there were protections against the dissemination of the results to third parties." ${ }^{379}$ An examination of the DNA testing statute at issue in King II, with these criteria in mind, reveals that the Maryland law stated explicitly the purposes of the testing. ${ }^{380}$ The purpose was to aid in criminal investigations, and that dissemination to third parties was considered a crime to be punished by law. ${ }^{381}$

Whether these and the several other distinctions offered by the Court on what appears to be a case-by-case basis are valid, it does not change the fact that the various explanations offered by the Court discussed above muddle the primary purpose test. In Edmond, for example, the Court's conclusion that the primary purpose of the drug interdiction checkpoint was the enforcement of criminal law was a reasonable one. ${ }^{382}$ What however of the state's contention that the checkpoints were designed to deal with the non-criminal major social problems incurred from the sale and use of illegal drugs? ${ }^{383}$ Certainly, as the Edmond Court acknowledged, both the direct problems that flow from drug use and their spin-off consequences are severe. ${ }^{384}$ One might argue that they are even more severe than those that come from the sale of stolen auto parts, the reduction of which is a non-criminal purpose, the Burger Court held to be severe enough to permit suspicionless searches. 385 The Court in Edmond responded to this by saying the issue is not the severity of the problem but the nature of the interests involved and the connection of the government procedure to the "particular law enforcement practices at issue." 386 The Court in Edmond did not enumerate specifically just what interests and practices it regarded as trumping the severity of the problem addressed.

As for the determining factor regarding why the checkpoint at issue could not be regarded as a special need, and therefore dispense with the requirement of individualized suspicion, the Court held that the primary purpose of such a checkpoint was to "advance 'the general interest in

\footnotetext{
$379 \quad I d$.

380 See MD. Code AnN., Pub. SAFETy $§ 2-505$ (2011) (proposing the purpose of DNA collection).

381 See $i d$. (stating the purpose of DNA collecting and testing); id. § 2-512 (describing the prohibited acts and associated penalties for improper DNA collecting and testing).

382 City of Indianapolis v. Edmond, 531 U.S. 32, 47-48 (2000).

383 See id. at 41-42 (noting the purpose of the checkpoint program).

384 See id. (discussing the severe social harms and law enforcement difficulties caused by narcotics).

385 See New York v. Burger, 482 U.S. 691, 724 (1987) (conveying the holding).

386 Edmond, 531 U.S. at $42-43$.
} 
Valparaiso University Law Review, Vol. 49, No. 3 [2015], Art. 8

crime control.'"387 In describing further the application of the primary purpose test, the Court in Edmond declared, "[w]e decline to suspend the usual requirement of individualized suspicion where the police seek to employ a checkpoint primarily for the ordinary enterprise of investigating crimes." 388

It was, however, for just such a purpose, the ordinary enterprise of investigating crimes, that the police in Lombard, Illinois established a roadblock. ${ }^{389}$ The roadblock was established to question all drivers passing through about a hit-and-run accident that had occurred in the general vicinity of the roadblock one week earlier. ${ }^{390}$ The Illinois Supreme Court, quite understandably, based its decision on the reasoning in Edmond, and held that the roadblock here violated the Fourth Amendment, and that evidence of drunk driving obtained from a driver who was stopped at the roadblock without individualized suspicion was inadmissible. ${ }^{391}$ In reversing this decision, the Supreme Court in Illinois $v$. Lidster used a different approach than it had taken in Edmond. ${ }^{392}$ The Court in Lidster noted that, unlike in Edmond, the roadblock here was not directed at the defendant but instead at seeking information from drivers who may have seen the hit-and-run accident. ${ }^{393}$ The Court then found several reasons within the language and facts of Edmond that distinguished the two cases. ${ }^{394}$

\footnotetext{
387 Id. at 44 (quoting Delaware v. Prouse, 440 U.S. 648, 659 n.18 (1979)).

388 Id. (emphasis added).

389 See Illinois v. Lidster, 540 U.S. 419, 422 (2004) (conveying the reason for a roadblock).

390 See id. at 422 (explaining how the checkpoint operated).

391 See People v. Lidster, 747 N.E.2d 417, 422 (Ill. App. Ct. 2001) (discussing the evidence collected at the roadblock was inadmissible because it was obtained without individualized suspicion).

392 See Lidster, 540 U.S. at 424 (stating that a lack individualized suspicion does not automatically atomically mean the practice violated the Fourth Amendment).

393 See id. at 423-24 (stating that the purpose of the checkpoint was not to detect criminal behavior, but rather it was it was to learn information about a recent incident, therefore it does not violate the Fourth Amendment). Even before the Court's decision in Lidster, which further confused the application of the primary purpose test, there was substantial misunderstanding of the test as it emerged from the decisions in Edmond and Ferguson. See Sandra J. Carnahan, The Supreme Court's Primary Purpose Test: A Roadblock to the National Law Enforcement Data Base, 83 NEB. L. REV. 1, 19-21 (2004) (noting that the "involuntary and suspicionless" collection of a defendant's DNA for CODIS fails the standard set forth in Edmond and Ferguson).

394 See Lidster, 540 U.S. at 424 (elaborating on Edmond). Lidster's Court states:
} Edmond['s] language, as well as its context, makes clear that the constitutionality of this latter, information-seeking kind of stop was not then before the Court. Edmond refers to the subject matter of its holding as "stops justified only by the generalized and ever-present possibility that interrogation and inspection may reveal that any given motorist has committed some crime." We concede that Edmond 
Once again, this distinction and the decision it led to may be reasonable, but the holding further confuses attempts to apply the primary purpose test. Additionally it allows, almost invites, the police to manipulate the claimed purpose of a seizure. ${ }^{395}$ For example, the court in Lidster referred to the purpose of the roadblock here as being "not to determine whether a vehicle's occupants were committing a crime[,] but to ask vehicle occupants, as members of the public, for their help in providing information about a crime[,] in all likelihood committed by others." 396 This invites several questions. Does this mean the determining factor regarding the need for individualized suspicion in conducting such a checkpoint depends on whether the suspicion relates to a past or current crime? If this were the meaning of the distinction between Edmond and Lidster, we would be left with the anomalous result that it would be easier for the police to use checkpoints to investigate past criminal conduct rather than the seemingly more pressing government need to investigate crimes that are ongoing or about to take place. ${ }^{397}$ Does it mean that whenever the police can convince a court that they were not looking for a suspect or tangible evidence of a crime, but only for information about a crime, that they may then lawfully intrude upon interests protected by the Fourth Amendment without individualized suspicion? The roadblock in Lidster was established to seek information about a hit and run fatal accident that had occurred one week earlier. ${ }^{398}$ While certainly a serious crime, sentences for murder, rape, and other crimes show governments' regard those crimes as of equal or greater seriousness than a hit and run accident. ${ }^{399}$ If police can

\footnotetext{
describes the law enforcement objective there in question as a "general interest in crime control," but it specifies that the phrase "general interest in crime control" does not refer to every "law enforcement objective."

Id.

Id. at 423

Id.

The Court's landmark holding in Terry $v$. Ohio permitted police investigative activity based on less than probable cause when criminal activity was "afoot." 392 U.S. 1, 30 (1968). While the court in United States $v$. Hensley later broadened this permissible police investigative activity to past crimes, that case was limited to seizures for past crimes that were felonies or threatened public safety. 469 U.S. 221, 227-28 (1985). Furthermore, the court in Hensley emphasized that the nature of the government interest in investigating past crimes was less than that in investigating crimes about to take place. Id. at 228-29.

398 Lidster, 540 U.S. at 422.

399 Illinois imposes a sentence of not less than four years and not more than fifteen years for class one felonies like rape. 730 ILL. COMP. STAT. 5/5-4.5-30 (2010). For first-degree murder, Illinois imposes the death sentence or imprisonment for not less than twenty years. Id. 5/5-4.5-20. Any person who leaves the scene of an accident when death occurs is guilty of a class one felony and a sentence of not less than four years and not more than fifteen years will be imposed. 625 ILL. COMP. STAT. 5/11-401. In West Virginia, an
} 
Valparaiso University Law Review, Vol. 49, N0. 3 [2015], Art. 8

seize every car, albeit for only a brief period of time, that passes the scene of a one-week-old accident, can they similarly seize every car driving or every person walking by the scene of a one-day-old rape or homicide at about the same time as the crime occurred? ${ }^{400}$ As with the purpose of the checkpoint in Lidster, the assumption here would be that people walking or driving by the scene of a recent crime at the location of the crime, might have been there as well on the crime date and observed something that would help the police apprehend a suspect. ${ }^{401}$ Of course, if the seizure is deemed to be valid, then the plain view rule or observations by the police made about an individual during the stop could authorize the seizure of contraband or as in Lidster's case, his arrest based on observed behavior. ${ }^{402}$

Even more confusion, however, is created by the last words of the Court in the above quoted passage, permitting checkpoints that ask individuals "about a crime in all likelihood committed by others." 403 If the perpetrator of the crime is somewhat likely to be discovered at a seizure, does this mean the detention is unlawful without individualized suspicion? In other words, should courts looking to apply the primary purpose test to police procedures authorizing seizures without individualized suspicion examine not just whether the purpose was merely to seek information from innocent people, but whether it was likely that the stops would involve only motorists unconnected to the crime being investigated? To accomplish this 180-degree gyration of

individual is sentenced to life in prison if found guilty of first-degree murder. W. VA. CODE ANN. § 61-2-2 (2014). For first-degree robbery, West Virginia imposes a sentence of at least ten years. Id. § 61-2-12(a)(1). Further, any person who leaves the scene of an accident when death occurs is guilty of a felony and shall be fined not more than $\$ 5000$ or imprisoned for not less than one year nor more than five years, or both fined and confined. Id. § 17C-41(b). In Rhode Island, an individual is sentenced to life in prison if found guilty of firstdegree murder. R.I. GEN. LAWS ANN. § 11-23-2 (2014). For first-degree robbery, Rhode Island imposes a sentence of not less than ten years imprisonment, and an individual may be imprisoned for life or fined not more than $\$ 15,000$, or both. Id. §11-39-1(a). Additionally, any person who leaves the scene of an accident when a death occurs shall be punished by imprisoned for not less than two years and for not more than fifteen years, by a fine of not less than $\$ 5000$ nor more than $\$ 10,000$, and his or her license to operate a motor vehicle shall be revoked for three years. $I d$. $\$ 31-26-1(\mathrm{~d})(1)$.

400 See Lidster, 540 U.S. at 422 (rationalizing the one-week-old accident roadblock).

401 Id. at 425. Additionally, the police could validly ask for consent to search the car or a person once the detention at the checkpoint is deemed to be lawful. See, e.g., Ohio v. Robinette, 519 U.S. 33, 38-39 (1996) (expanding on what police can do at a lawful checkpoint).

402 Lidster, 540 U.S. at 422 . The plain view rule allows for the police to seize evidence if they are in a place they have a right to be, see or in some way use their senses to detect the evidence, and have probable cause to believe what they see is evidence of a crime. See, e.g., Illinois v. Andreas, 463 U.S. 765, 771 (1983) (explaining the plain-view doctrine).

403 Lidster, 540 U.S. at 423. 
what normally needs to be shown to justify the government's right to search or seize under the Fourth Amendment, the police would apparently have to show that they did not have individualized suspicion or probable cause of criminal activity regarding the seized car or individual. At the very least, they would seemingly have to show that they had no information that the car or person stopped had any involvement in the crime that the police were investigating.404 Additionally, in attempting to divine the "true" purpose of the police seizure at issue, a court would risk the very problems described by the Supreme Court when it permitted pretext stops in Whren $v$. United States based only on whether the officer's action was objectively reasonable. ${ }^{405}$

\section{The Test Protects the Wrong People and for No Good Reason}

Ironically, amid the confusion surrounding the Court's use of the primary purpose test, the one clear principle that emerges from the Court's applications of the test is that it protects groups of people suspected of crimes more than those about whom there is no suspicion. ${ }^{406}$ The test requires the government to have individualized suspicion when the primary purpose of the search or seizure is to apprehend a criminal or obtain evidence of a crime, but excuses similar suspicionless intrusions when the primary purpose addresses

404 When the Supreme Court in California v. Acevedo modified its interpretation of the Fourth Amendment regarding the search of containers located in automobiles, it noted the anomaly of prohibiting such searches without warrants when the police had probable cause there was evidence of a crime within the specific container but permitting such searches when the probable cause went to the vehicle in general. 500 U.S. at 565, 577 (1991). In other words, the more the police knew, the less they could accomplish. Such an anomaly is similar to the interpretation of the primary purpose test alluded to above where the police would have to show they did not believe a suspect was in the vehicle to authorize its seizure at a roadblock. A similar anomaly existed with application of the plain view rule before the Court's decision in Horton v. California, 496 U.S 128 (1990). Before Horton, to seize evidence under the plain view rule, the police had to prove they did not have probable cause that the evidence they ultimately seized was located in the place from where the seizure took place. Horton eliminated the requirement that the finding of the evidence needed to be inadvertent for the plain view rule to apply. Id. at 130.

405517 U.S. 806, 815 (1996); see Atwater v. City of Lago Vista, 532 U.S. 318, 354 (2001) (discussing the Court's refusal to place any relevance on the reason why a police officer chose to exercise his discretion to make an arrest when he could have issued a citation); Butterfoss, supra note 341, at 484 (arguing that it would be even more difficult to divine the primary purpose of investigative activity in the "collective consciousness" of the police for establishing program such as checkpoints or the DNA testing of all arrestees charged with serious crimes).

406 George M. Dery \& Kevin Meehan, Making the Roadblock a "Routine Part of American Life:" Illinois v. Lidster's Extension of Police Checkpoint Power, 32 AM. J. CRIM. L. 105, 120-21 (2004). 
individuals not suspected of crime. ${ }^{407}$ For this apparent anomaly to be permitted, there would need to be a substantial reason to justify it. 408 In searching for such a reason, one needs to explore the well-established test for Fourth Amendment reasonableness. ${ }^{409}$ The use of this test has characterized much of the jurisprudence surrounding searches and seizures that take place without the presence of individualized suspicion. That test requires balancing the extent of the intrusion in an area protected by the Fourth Amendment against the government's need to do so. ${ }^{410}$ In analyzing the extent of the intrusion, the Court has examined both the physical and subjective intrusions that result from the government's action. ${ }^{411}$ For example, the Court has permitted certain seizures without individualized suspicion when systematically checking for undocumented aliens at checkpoints, but not when random cars are pulled over for the same purpose. ${ }^{412}$ In the latter situation, the Court required articulable individualized suspicion to stop a car. ${ }^{413}$ The distinction between the two types of seizures, according to the Court, relates to the subjective nature of the intrusions. ${ }^{414}$ The Court found that the regularity and other aspects of checkpoint stops create less apprehension in the driver than being pulled over at random. 415

In comparing the extent of the intrusions at checkpoints designed to look for evidence of a crime such as the one in Edmond, with those seeking information of a past crime, such as in Lidster, the physical nature of the intrusion is essentially the same. ${ }^{416}$ The driver and his or her passengers are seized in a way that implicates the Fourth Amendment. ${ }^{417}$ In each, they may be detained only briefly. 418 Additionally, no search of the car is permitted without consent or the

\footnotetext{
407 See supra Part VII (addressing Fourth Amendment jurisprudence and the primary purpose test).

408 See Camara v. Mun. Court, 387 U.S. 523, 530 (1967) (explaining criminal behavior as a substantial justification). "It is surely anomalous to say that the individual and his private property are fully protected by the Fourth Amendment only when the individual is suspected of criminal behavior." Id.

409 See Maryland v. King (King II), 133 S. Ct. 1958, 1968 (2013) (discussing reasonableness).

410 See supra Part V (describing the balancing test).

411 See supra Part V.A (establishing the Court's analysis of intrusion).

412 United States v. Martinez-Fuerte, 428 U.S. 543, 567-68 (1976); Almeida-Sanchez v. United States, 413 U.S. 266, 273-75 (1973).

$413 \quad$ Almeida-Sanchez, 413 U.S. at 273-75.

414 Martinez-Fuerte, 528 U.S. at 559.

415 Id.; United States v. Brignoni-Ponce, 422 U.S. 873, 880-81 (1975).

416 See Dery \& Meehan, supra note 405, at 126-29 (comparing Lidster and Edmond).

417 Id.

$418 \quad$ Id
} 
presence of the appropriate degree of individualized suspicion. ${ }^{419}$ If evidence of a crime has nothing to do with the reason for the checkpoint becomes apparent, the police may seize it under the plain view rule. ${ }^{420}$

Regarding the subjective nature of the intrusion, one commentator has characterized a somewhat different, but analytically similar, situation in a manner that raises further doubt about the efficacy of the primary purpose test:

As a law-abiding citizen, the government purpose behind a government intrusion matters very little to me-it is the intrusion itself that concerns and bothers me. To use the traffic checkpoint as an example, I am irritated and inconvenienced by the fact that my ability to continue on my way is interfered with when I have done nothing to give the government reason to suspect me of wrongdoing. It is no comfort to me that the government intrusion is merely for a "regulatory" purpose. In fact, just the opposite may be true;[] I am more likely to be bothered by a "non-criminal" intrusion. Catching criminals seems more important to me than checking licenses and registrations,[] so I am more willing to understand and appreciate the need for the government to act,[] especially since I am not a criminal. If the stop is for a regulatory purpose, I may be affected and inconvenienced to a greater extent. I do not have drugs in my car, but I may have forgotten my license, registration or insurance card, or they may have lapsed by a few days. While the consequences are unlikely to be grave, they will inconvenience me by costing me time and money.[] And I am likely to be even more upset because "I wasn't doing anything wrong" when the government discovered my errors. I am much less likely to complain if I am caught speeding and the license and registration offenses are discovered collateral to that. I am still inconvenienced and not

419 See id. at 121-22 ("the... 'general crime control' purpose versus the 'informationseeking' purpose might appear to be a distinction without a difference, ... [a] driver might wonder exactly how the stop is less intrusive just because the police are bothering him or her about someone else"). These authors then characterize the objective nature of the intrusions permitted by the Court in Lidster but prohibited in Edmond to be "monotonously similar." Id.

420 City of Indianapolis v. Edmond, 531 U.S. 32, 35 (2000) (elaborating on the open-view principle). 
happy, but I am less likely to feel I have been treated unfairly or the government has been overbearing. And a license and registration check in the middle of the day on my usual route to work or shopping or recreation certainly makes it seem that traffic checkpoints have become more "an everyday part of American life" than a sobriety checkpoint in the early morning hours in the vicinity of bars or a narcotics checkpoint along routes frequented by drug traffickers. ${ }^{421}$

In any event, it is hard to conclude that an innocent person would have any more reason to be upset about being seized as part of a narcotics interdiction campaign than to be seized to be asked about a past crime. ${ }^{422}$ Additionally, the checkpoints conducted in Edmond operated generally during the day whereas the one in Lidster was conducted late at night, when presumably a motorist would be more apprehensive about being detained. ${ }^{423}$

The second part of the Fourth Amendment reasonableness test relates to the importance of the government's need to conduct the search or seizure in question and its effectiveness at achieving this purpose. ${ }^{424}$ In Lidster, the police established the checkpoint to inquire about a fatal hit-and-run accident that had occurred in the vicinity. ${ }^{425}$ In Edmond, checkpoints were set up based on, among other things, crime statistics and traffic flow. 426 The purpose of the checkpoints in Edmond was to interdict the flow of drugs into a city that had felt the terrible effects of the rampant use of illegal drugs. ${ }^{427}$ It is not dismissive of the seriousness of the need to investigate a past hit and run fatality to recognize that the roadblock established in Lidster was directed at only one crime. ${ }^{428}$ The roadblocks in Edmond were established to prevent many drug crimes and violence that flows directly and indirectly from such crimes. ${ }^{429}$ It is difficult to see how an argument could be made that the government's need in Edmond was any less than that in Lidster or more generally about

\footnotetext{
421 See Butterfoss, supra note 341, at 487-88 (referencing a paragraph from Mr. Butterfoss' article detailing the purpose behind traffic stops and the effects it has on innocent individuals).

422 See Dery \& Meehan, supra note 405, at 121 (comparing the differences between Lidster and Edmond and each of their purposes for traffic stops).

423 Id. at $111,114$.

424 See supra Part VI.A (discussing the nature of government interest).

425 Illinois v. Lidster, 540 U.S. 419, 422 (2004).

426 City of Indianapolis v. Edmond, 531 U.S. 32, 35-36 (2000).

427 Id. at $41-42$.

428 Lidster, 540 U.S. at 427.

429 See Edmond, 531 U.S. at 34-36 (conveying the facts of the case).
} 
why searches or seizures whose primary purpose is to investigate crime is less important than those whose purposes are claimed to be otherwise.

In conclusion, attempting to determine the legality of searches and seizures that are conducted without individualized suspicion based on whether the primary purpose of the investigative activity was to ferret out ordinary criminal wrongdoing leads to results that are difficult to understand, make little sense when they can be understood, encourage police manipulation, and work in opposition to Fourth Amendment principles. A more effective way to make this determination should be used, and in fact, already exists. ${ }^{430}$

\section{CONCLUSION}

This Article has addressed the constitutionality of obtaining DNA samples from arrestees and using those samples to identify the arrestee and compare his DNA sample to those found at the scene of serious crimes. The Article maintains that neither the presumption of innocence nor the arguments surrounding the Fourth Amendment are reasons for invalidating such testing. Specifically, the presumption of innocence is basically a trial protection and has no bearing on the legality of a search or seizure. 431 The test by which the Court determines the legality of a search or seizure is to balance the extent of the intrusion against the importance of the government's interest in conducting the search or seizure. 432 The DNA testing of arrestees accomplishes the important purpose of solving outstanding crimes, thus linking the guilty to the crime and exonerating those who may have been wrongly charged. 433

More broadly, this Article points to a better way for courts to apply the reasonableness test to searches or seizures done without individualized suspicion. Courts should avoid being disingenuous and misleading when analyzing aspects of this reasonableness test such as the primary purpose of the intrusion, and whether and to what extent the subject of the intrusion has a diminished expectation of privacy. When it approved the suspicionless DNA testing of arrestees in King II, the Court deemphasized what was the actual primary purpose of the

430 Such an approach balances the extent of the intrusion against the need of the government to engage in it. The first part of the balancing test includes consideration of whether the subject of the intrusion already has a diminished expectation of privacy. The second part of the test encompasses the effectiveness of the government's intrusion in accomplishing its purpose.

431 See supra notes 114-21 and accompanying text (analyzing cases that determined DNA testing constituted a search).

432 See supra Part V.A (discussing the level of intrusion).

433 See supra Part V.A.2 (supporting the theory that DNA testing provides a more reliable evidence to determine a defendant's guilt or innocence). 
Valparaiso University Law Review, Vol. 49, No. 3 [2015], Art. 8

test - the use of the samples to help solve crimes.434 Instead, the Court focused on how the samples could confirm the "identification" of the arrestee. ${ }^{435}$ Apparently this was done so the Court could avoid the holdings in some previous cases, which held that suspicionless Fourth Amendment intrusions were lawful only when their primary purpose was other than to ferret out crime. This partial masking of the actual purpose of the testing in fact weakened the Court's holding in King II and served as fodder for Justice Scalia's stinging dissent.

It is undisputed that an arrestee has a diminished expectation of privacy because of his confinement. 436 What should be an especially significant aspect in analyzing the extent of intrusion however is compromised by the manner in which the Court has applied the diminished expectation of privacy principle in the past. When it approved the suspicionless drug testing of certain students, the Court wrote that all students subjecting themselves to extra-curricular activities have a diminished expectation of privacy as compared to other students. 437 If the Court wished to sanction drug testing students because of the government's need to insure that students do not come to school high on drugs and because the schools act in loco parentis, it should have said so. This would apply to all students and although a debatable conclusion, would foster an honest analysis. However, applying the diminished expectation of privacy rationale to students because they participate in extracurricular activities was unpersuasive and counterproductive to developing a rational way of applying the reasonableness test. It is reasonable to conclude, as the Court has, that one has less of an expectation of privacy in a car than in a home from the "pervasive regulation" of automobiles. ${ }^{438}$ This hardly leads to the

434 See supra Part VII (analyzing the King II opinion on the primary reasoning for the use of DNA testing).

${ }_{435}$ See supra Part VIII (providing that identification was a main focus of the court in King

II).

436 See supra notes 260-88 and accompanying text (reviewing case law which established a lower expectation of privacy for individuals incarcerated).

437 See supra notes 302-07 and accompanying text (concluding that Earl's decision lowered the expectation of privacy for students).

438 California v. Carney, 471 U.S. 386, 392 (1985). Originally the Court held this reduced expectation of privacy developed from the ready mobility of automobiles. Carroll v. United States, 267 U.S. 132, 146, 151, 162 (1925). Over time, the Court developed a second rationale for this reduced privacy expectation-the fact that automobiles are highly regulated. As the Court wrote in South Dakota v. Opperman:

Automobiles, unlike homes, are subjected to pervasive and continuing governmental regulation and controls, including periodic inspection and licensing requirements. As an everyday occurrence, police stop and examine vehicles when license plates or inspection stickers have expired, or if other violations, such as exhaust fumes or excessive 
conclusion that although the police require a warrant before they can open a paper bag carried openly by a person in the street that they are excused from the warrant requirement when that bag is locked up in a suitcase and placed in the trunk of an automobile as the Courts holdings indicate. ${ }^{439}$ Although the Court has used the diminished expectation of privacy in these dubious ways, it should not take away from its significance when the subject of the intrusion has a genuine and substantial diminished expectation of privacy-as do arrestees in full custodial institutions. ${ }^{440}$ In such situations, this diminished expectation of privacy severely reduces the extent of the intrusion to the individual.

Finally, this Article has reviewed those cases in which the Court has used the primary purpose test as a determining factor in analyzing whether suspicionless government intrusions violate the Fourth Amendment. Those cases are extremely inconsistent in both the definition and application of the test. ${ }^{441}$ In fact, the primary purpose test works to permit more substantial intrusions on those not suspected of criminal activity than for those who are suspected. ${ }^{442}$ Accordingly, the primary purpose test needs to be abandoned, or at least revisited by the Court, regarding its role in the application of the Fourth Amendment.

noise, are noted, or if headlights or other safety equipment are not in proper working order.

428 U.S. 364,368 (1976).

439 See, e.g., California v. Acevedo, 500 U.S. 565, 580 (1991) (establishing that police had probable cause to view the contents of a brown paper bag that was located in the trunk of a vehicle).

440 See supra notes 260-88 and accompanying text (reiterating the fact the incarcerated defendants do not share the same level of privacy as other citizens in the United States enjoy).

${ }_{441}$ See supra Part V (reviewing how the level of intrusion has been interrupted by the courts).

442 See supra Part VI.C (illustrating that the courts have laid the foundation for protecting the privacy of people suspected of criminal activity, than those individuals who are not). 
